\title{
Long-term field performance of a tunable diode laser absorption spectrometer for analysis of carbon isotopes of $\mathrm{CO}_{2}$ in forest air
}

\author{
S. M. Schaeffer ${ }^{1, *}$, J. B. Miller ${ }^{2,3}$, B. H. Vaughn ${ }^{4}$, J. W. C. White ${ }^{4}$, and D. R. Bowling ${ }^{1,5}$ \\ ${ }^{1}$ Department of Biology, University of Utah, Salt Lake City, UT 84112, USA \\ ${ }^{2}$ National Oceanic and Atmospheric Administration, Earth System Research Laboratory, Boulder, CO 80305, USA \\ ${ }^{3}$ Cooperative Institute for Research in Environmental Science, University of Colorado, Boulder, CO 80309, USA \\ ${ }^{4}$ Institute for Arctic and Alpine Research, University of Colorado, Boulder, CO 80302, USA \\ ${ }^{5}$ Stable Isotope Ratio Facility of Environmental Research, University of Utah, Salt Lake City, UT 84112, USA \\ " now at: Department of Ecology, Evolution, and Marine Biology, University of California, Santa Barbara, CA 93106, USA
}

Received: 12 March 2008 - Published in Atmos. Chem. Phys. Discuss.: 26 May 2008

Revised: 29 July 2008 - Accepted: 12 August 2008 - Published: 5 September 2008

\begin{abstract}
Tunable diode laser absorption spectrometry (TDLAS) is gaining in popularity for measuring the mole fraction $\left[\mathrm{CO}_{2}\right]$ and stable isotopic composition $\left(\delta^{13} \mathrm{C}\right)$ of carbon dioxide $\left(\mathrm{CO}_{2}\right)$ in air in studies of biosphere-atmosphere gas exchange. Here we present a detailed examination of the performance of a commercially-available TDLAS located in a high-altitude subalpine coniferous forest (the Niwot Ridge AmeriFlux site), providing the first multi-year analysis of TDLAS instrument performance for measuring $\mathrm{CO}_{2}$ isotopes in the field. Air was sampled from five to nine vertical locations in and above the forest canopy every ten minutes for 2.4 years. A variety of methods were used to assess instrument performance. Measurement of two compressed air cylinders that were in place over the entire study establish the long-term field precision of $0.2 \mu \mathrm{mol} \mathrm{mol}^{-1}$ for $\left[\mathrm{CO}_{2}\right]$ and $0.35 \%$ o for $\delta^{13} \mathrm{C}$, but after fixing several problems the isotope precision improved to $0.2 \%$ (over the last several months). The TDLAS provided detail on variability of $\delta^{13} \mathrm{C}$ of atmospheric $\mathrm{CO}_{2}$ that was not represented in weekly flask samples, as well as information regarding the influence of largescale (regional) seasonal cycle and local forest processes on $\left[\mathrm{CO}_{2}\right]$ and $\delta^{13} \mathrm{C}$ of $\mathrm{CO}_{2}$. There were also clear growing season and winter differences in the relative contributions of photosynthesis and respiration on the $\left[\mathrm{CO}_{2}\right]$ and $\delta^{13} \mathrm{C}$ of forest air.
\end{abstract}

\section{Introduction}

Measurement of the stable isotope ratios of gases that participate in biosphere/atmosphere exchange processes is

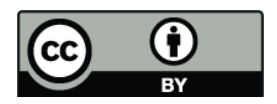

Correspondence to: D. R. Bowling (bowling@biology.utah.edu) necessary to understand those processes and the natural environment (Keeling et al., 1995; Trolier et al., 1996). Instruments that separately measure absorption of isotopomers of gases of interest (e.g. ${ }^{13} \mathrm{CO}_{2}$ and ${ }^{12} \mathrm{CO}_{2}$ ) (Murnick and Peer, 1994) provide an alternative to isotope ratio mass spectrometry (IRMS) techniques (Brand, 1996). Laser absorption spectrometry has regularly been used to measure the mole fractions of atmospheric trace gases such as $\mathrm{CH}_{4}, \mathrm{CO}$, $\mathrm{N}_{2} \mathrm{O}$, and others (Gulluk et al., 1997; Webster et al., 2001; Provencal et al., 2005). These instruments measure absorption of mid-infrared (mid-IR) radiation using a variety of techniques including Fourier-transform IR spectroscopy (Esler et al., 2000; Griffith et al., 2000), quantum cascade laser spectroscopy (Weidmann et al., 2004; McManus et al., 2005; Saleska et al., 2006), cavity ring-down spectroscopy (Crosson et al., 2002; Provencal et al., 2005; Wahl et al., 2006), and laser optogalvanic effect spectroscopy (Murnick and Okil, 2005). Another method that has received considerable attention in ecological and atmospheric studies is tunable diode laser absorption spectroscopy (TDLAS). Bowling et al. (2003) described in detail a TDLAS instrument capable of measuring ${ }^{12} \mathrm{CO}_{2}$ and ${ }^{13} \mathrm{CO}_{2}$ at natural abundance levels. Several recent studies have used TDLAS instruments to address questions of ecological relevance with stable isotopes. These studies examined the $\delta^{13} \mathrm{C}$ and $\delta^{18} \mathrm{O}$ of ecosystem-respired $\mathrm{CO}_{2}$ (Griffis et al., 2004; Bowling et al., 2005; Griffis et al., 2005a; Griffis et al., 2005b; Zhang et al., 2006; Griffis et al., 2007), $\delta^{13} \mathrm{C}$ and $\delta^{18} \mathrm{O}$ of leaf-respired $\mathrm{CO}_{2}$ (Barbour et al., 2007a, 2007b), and $\delta^{18} \mathrm{O}$ of water vapor in forest air (Lee et al., 2005).

The isotopic composition of atmospheric $\mathrm{CO}_{2}$ is useful in improving our understanding of biosphere-hydrosphereatmosphere interactions. At the global scale, the carbon isotopic composition of atmospheric $\mathrm{CO}_{2}$ is affected by the relative strengths of land/ocean carbon sinks (Ciais et al., 1995;

Published by Copernicus Publications on behalf of the European Geosciences Union. 
Francey et al., 1995; Scholze et al., 2003) and the release of fossil fuel-derived $\mathrm{CO}_{2}$ (Bakwin et al., 1998). Annual trends and ice/firn records show that as $\left[\mathrm{CO}_{2}\right]$ has risen, $\delta^{13} \mathrm{C}$ of $\mathrm{CO}_{2}$ has decreased (Trolier et al., 1996; Francey et al., 1999; Allison and Francey, 2007). However, there are important seasonal changes in $\delta^{13} \mathrm{C}$ of atmospheric $\mathrm{CO}_{2}$ related to biogeochemical cycling of carbon and anthropogenic inputs. Flask sampling has been used to quantify these patterns in $\left[\mathrm{CO}_{2}\right]$ and $\delta^{13} \mathrm{C}$ over the scale of months to multiple years (Trolier et al., 1996). However, most flask sampling occurs on the time-scale of weeks on average, and shorter-term (e.g. diurnal) fluctuations may not be observed. Conversely, at leaf to ecosystem scales the $\delta^{13} \mathrm{C}$ of $\mathrm{CO}_{2}$ is mostly affected by photosynthesis (Farquhar et al., 1989) and by respiration from all autotrophic and heterotrophic organisms (Bowling et al., 2008). Studies at these scales using flask-based sampling approaches may have temporal resolution on the order of hours (Knohl, 2003; Ogee et al., 2003), but lack seasonal or inter-annual resolution, and those that do address these timescales lack diurnal resolution (Lai et al., 2005; Alstad et al., 2007). TDLAS has the potential to greatly increase the number of measurements made at a single location and bridge the gap between diurnal and inter-annual timescales. For example, Barbour et al. (2007a, 2007b) used a TDLASbased approach to measure $\delta^{13} \mathrm{C}$ and $\delta^{18} \mathrm{O}$ of leaf darkrespired $\mathrm{CO}_{2}$ on the scale of minutes. Bowling et al. (2005) used TDLAS measurements of $\mathrm{CO}_{2}$ and $\delta^{13} \mathrm{C}$ in forest air to gain temporal and spatial resolution that allowed them to characterize diurnal patterns of $\left[\mathrm{CO}_{2}\right]$ and $\delta^{13} \mathrm{C}$ at 9 different heights in a coniferous forest canopy on a 6 minute timescale over a single growing season.

In order to be useful in most ecological and atmospheric studies, TDLAS-based techniques should have precision approaching that achievable using isotope ratio mass spectrometry (IRMS). Typical precision for IRMS is 0.02 to 0.06 for $\delta^{13} \mathrm{C}$ of $\mathrm{CO}_{2}$ at atmospheric mole fractions (Trolier et al., 1996; Vaughn et al., 2004; Schauer et al., 2005; Fisher et al., 2006). Of the mid-IR optical absorption spectroscopy techniques mentioned above, a study using Fouriertransform IR spectroscopy obtained precision of $0.1 \% \circ \delta^{13} \mathrm{C}$ at $350 \mu \mathrm{mol} \mathrm{mol}^{-1} \mathrm{CO}_{2}$ (Esler et al., 2000), a quantum cascade study obtained $0.18 \% \circ \delta^{13} \mathrm{C}$ at $350 \mu \mathrm{mol} \mathrm{mol}^{-1} \mathrm{CO}_{2}$ (McManus et al., 2005), and studies using cavity ringdown spectroscopy with cryogenic preconcentration reported $0.25 \%$ o $\delta^{13} \mathrm{C}$ at $350 \mu \mathrm{mol} \mathrm{mol}^{-1} \mathrm{CO}_{2}$, or $0.22 \%$ at higher (human breath) mole fractions (Crosson et al., 2002; Wahl et al., 2006). Precisions reported for TDLAS instruments vary from 0.03 to $0.15 \mu \mathrm{mol} \mathrm{mol}^{-1}$ for $\mathrm{CO}_{2}$ and 0.03 to $4 \%$ for $\delta^{13} \mathrm{C}$ (Becker et al., 1992; Bowling et al., 2003, 2005; Griffis et al., 2004; Pataki et al., 2006; Barbour et al., 2007b). Several methods for determining the precision of TDLAS measurements have been used in these studies and hence direct comparison of instrument performance is problematic.

The objective of the present study is to evaluate the longterm performance of a TDLAS used to monitor $\left[\mathrm{CO}_{2}\right]$ and $\delta^{13} \mathrm{C}$ of atmospheric $\mathrm{CO}_{2}$ within a subalpine forest at Niwot Ridge, Colorado, USA. The sampling methodology was designed to observe diurnal and seasonal variations related to local forest carbon cycling processes as well and regional changes in atmospheric $\mathrm{CO}_{2}$. Based on a preliminary study (Bowling et al., 2005), we were uncertain if TDLAS was capable of providing detail on the relatively small-amplitude seasonal cycle in $\delta^{13} \mathrm{C}$ of atmospheric $\mathrm{CO}_{2}$ in the air above this forest. The potential drawback of a TDLAS-based approach in this case is that the regional variability in the troposphere at the latitude of Niwot Ridge $\left(40^{\circ} \mathrm{N}\right)$ is known to be $\sim 0.5 \%$ o (Trolier et al., 1996), which is close to the precision found for TDLAS instruments in several studies. However, seasonal variability should still be detectable using TDLAS if the accuracy is high and the noise averages away.

We hypothesized that the high temporal and spatial resolution of TDLAS measurements would show that the $\delta^{13} \mathrm{C}$ of $\mathrm{CO}_{2}$ in forest air is affected by both local forest processes and regional phenomena (such as the seasonal cycle). As mentioned, flask-based approaches lack the combination of spatial and temporal resolution provided by TDLAS measurements. We know from previous studies that forest carbon cycling processes affect the $\delta^{13} \mathrm{C}$ of forest air (Pataki et al., 2003; Bowling et al., 2008; Schaeffer et al., 2008) and at the regional and global scales $\left[\mathrm{CO}_{2}\right]$ and $\delta^{13} \mathrm{C}$ are increasing/decreasing due to anthropogenic processes (Trolier et al., 1996; Scholze et al., 2003). However, the relative importance of these processes has not been thoroughly examined at a single site, and little is known about how the seasonal cycle variability in regional air is modified by local forest processes. The assumption has been previously made that the $\mathrm{CO}_{2}$ in air interacting with a forest is similar to the marine baseline at the same latitude (Lai et al., 2004). We predicted that during the winter, $\delta^{13} \mathrm{C}$ would drop as ecosystem respiration added $\mathrm{CO}_{2}$ depleted in ${ }^{13} \mathrm{C}$ to the air, and during the growing season $\delta^{13} \mathrm{C}$ would increase as plant photosynthesis discriminated against ${ }^{13} \mathrm{C}$, leaving forest air enriched in ${ }^{13} \mathrm{C}$ during the day (higher $\delta^{13} \mathrm{C}$ ). We also expected that over the course of the study, baseline $\left[\mathrm{CO}_{2}\right]$ would increase and $\delta^{13} \mathrm{C}$ would decrease with global changes in atmospheric $\mathrm{CO}_{2}$.

In this paper, we describe the analytical details of the sampling system as well as the sampling and data analysis procedures that were used to assess the performance of this fielddeployed TDLAS system. We then use the resulting 2.4-year record to examine the relative importance of local and largescale processes on the isotopic composition of forest air.

\section{Methods}

\subsection{Site description}

The study site, the Niwot Ridge AmeriFlux forest, is a subalpine coniferous forest in the Rocky Mountains of northcentral Colorado, United States $\left(40.03^{\circ} \mathrm{N}, 105.55^{\circ} \mathrm{W}\right)$. 
Elevation at the site is 3050 meters above sea level (masl), the average annual precipitation is $800 \mathrm{~mm}$, and average annual temperature is $1.5^{\circ} \mathrm{C}$. Net ecosystem carbon, water, and energy fluxes, and weather have been monitored continuously at this site since the fall of 1998 (Monson et al., 2002; Turnipseed et al., 2002; Sacks et al., 2006). The forest is an approximately 100 year old mixed-species subalpine forest composed of Abies lasiocarpa (Hook.) Nutt. (subalpine fir), Picea engelmannii Parry ex Engelm. (Engelmann spruce), and Pinus contorta Dougl. Ex Loud. (lodgepole pine). The sparse understory contains seedlings of all three tree species and scattered patches of Vaccinium myrtillus $\mathrm{L}$.

\subsection{Tunable Diode Laser Sampling System}

Bowling et al. (2003) described in detail a commercial TDLAS instrument for measuring ${ }^{12} \mathrm{CO}_{2}$ and ${ }^{13} \mathrm{CO}_{2}$ at natural abundance levels and mole fractions. Briefly, temperature and electrical current can be controlled in order to induce laser emission at desired wavelengths over a very narrow band. The tunable nature of this technique allows resolution of individual absorption peaks for ${ }^{12} \mathrm{CO}_{2}$ and ${ }^{13} \mathrm{CO}_{2}$.

For the present study, measurements of $\left[\mathrm{CO}_{2}\right]$ and $\delta^{13} \mathrm{C}$ in forest air were made using a tunable diode laser absorption spectrometer (TDLAS, TGA100A, Campbell Scientific, Inc., Logan, Utah). The absorption lines used for this study were 2293.881 and $2294.481 \mathrm{~cm}^{-1}$ for ${ }^{12} \mathrm{CO}_{2}$ and ${ }^{13} \mathrm{CO}_{2}$ respectively. The TDLAS was housed in an insulated, unheated shack at Niwot Ridge. A related preliminary experiment at the same location has been reported previously (Bowling et al., 2005). Measurements for the present study began 13 September 2005 (day of year, DOY 256), and data collection is ongoing. Performance parameters are evaluated in this paper for data collected through 22 February 2008 (DOY 53), a total time period of 2.44 years. Most analyses in this paper focus on the first 2 years, but some additional analyses were performed with the longer data set to show system improvements. A custom-built multi-inlet sampling manifold allowed automated sampling of air from multiple locations (Fig. 1). This inlet system differs substantially from the one used by Bowling et al. (2005). Air was sampled from different heights from a tower and from a series of calibration tanks. Air samples were collected using $0.64 \mathrm{~cm}$ o.d. tubing (Type 1300, Synflex Specialty Products, Mantua, $\mathrm{OH}$ ). Tubing inlets were screened with $1 \mu \mathrm{m}$ air filters (\#130610, Nuclepore, Whatman, Maidstone, Kent, UK) held in place with $25 \mathrm{~mm}$ open-face filter holders (\#1107, Pall Gelman Laboratory, Ann Arbor, Michigan, USA). A bypass pump was used to continually flush inlet tubing at $\sim 1 \mathrm{~L} \mathrm{~min}^{-1}$ for each inlet line (RAA series, Gast Manufacturing Inc., Beech House, Loudwater, High Wycombe, Bucks, UK). Gas from calibration tanks was not filtered, and only flowed during measurement. Each air and tank sample was passed into one position on a 20-position aluminum manifold (1548220, Clippard Instrument Laboratory Inc., Cincinnati, Ohio,
USA) fitted with two-way, normally closed solenoid valves (EC-2-12VDC, Clippard Instrument Laboratory Inc., Cincinnati, Ohio, USA). A glass rod was inserted into the internal volume of the manifold and gas was drawn from both ends of the manifold to reduce dead volume. Downstream of the manifold, gas was routed through $0.32 \mathrm{~cm}$ o.d. stainless steel tubing and a $15 \mu \mathrm{m}$ filter (Nupro SS-4FW-15, Swagelok Company, Solon, Ohio, USA), and the flow rate to the TDLAS controlled at 100 to $400 \mathrm{~mL}$ (STP) $\mathrm{min}^{-1}$ using a mass flow controller (Type 1179A, MKS Instruments, Andover, Massachusetts, USA). The air pressure upstream of the mass flow controller was continuously monitored using an ultrahigh purity pressure transducer with low internal volume (GCT225, Setra Systems Inc., Boxborough, Massachusetts, USA); manifold pressure was used to diagnose problems such as clogged tubing, malfunctioning solenoids, etc. Prior to entry into the TDLAS, air was dried using a Nafion counterflow system (PD 625, Campbell Scientific, Inc., Logan, Utah). Finally, a dry rotary vacuum pump (XDS5, BOC Edwards, Crawley, West Sussex, UK) downstream of the TDLAS was used to pull gas from the manifold, through the mass flow controller and nafion drier, and through the TDLAS. Care was taken to keep flow rates through the sampling manifold and TDLAS constant; the pressure in the TDLAS sample cell varied from 2 to $2.5 \mathrm{kPa}$ over the study but was usually kept constant using the flow controller. Care was taken to minimize the volume of the inlet system between the valve manifold and the TDLAS, which allowed plumbing transients to disappear more quickly.

\subsection{Air sampling, calibration, and quality control}

Data collection and sampling system control were achieved using a datalogger (CR5000, Campbell Scientific, Inc., Logan, Utah, USA). From the start of sampling through April 27, 2006 (DOY 117), six heights in and above the canopy were sampled (two locations at $0.1 \mathrm{~m}$ and one each at 2,5 , 11 , and $21.5 \mathrm{~m}$ above the ground), as well as four calibration gases in a 10-min cycle. After day 117, 2006, one site was removed $(0.1 \mathrm{~m})$ and four additional sites were added $(0.5$, 1,7 , and $9 \mathrm{~m}$ ), which along with the four calibration gases made for a total of 13 sites measured every $10 \mathrm{~min}$ cycle. Air from a given site was initially sampled for $60 \mathrm{~s}$ to allow the plumbing to flush and pressure transients $(<20 \mathrm{~Pa})$ to dissipate in the TDLAS sample cell. After day 117, 2006, this flushing time was decreased to $46 \mathrm{~s}$ for the first 12 sites, and $48 \mathrm{~s}$ for the last site in order to keep the cycle time to $10 \mathrm{~min}$. Data from the last $10 \mathrm{~s}$ of each site were averaged to produce a measurement. Hereafter, this is referred to as the 10-s mean $\left(\mathrm{X}_{10}\right)$, with a corresponding 10 -s standard deviation $\left(\sigma_{10}\right)$.

Calibration gases were $\mathrm{CO}_{2}$-in-air mixtures that were filled with ambient air using a custom compressor system at the Stable Isotope Ratio Facility for Environmental Research, University of Utah (SIRFER). Above-ambient $\left[\mathrm{CO}_{2}\right]$ in the tanks was obtained by addition of pure $\mathrm{CO}_{2}$ with $\delta^{13} \mathrm{C}$ 


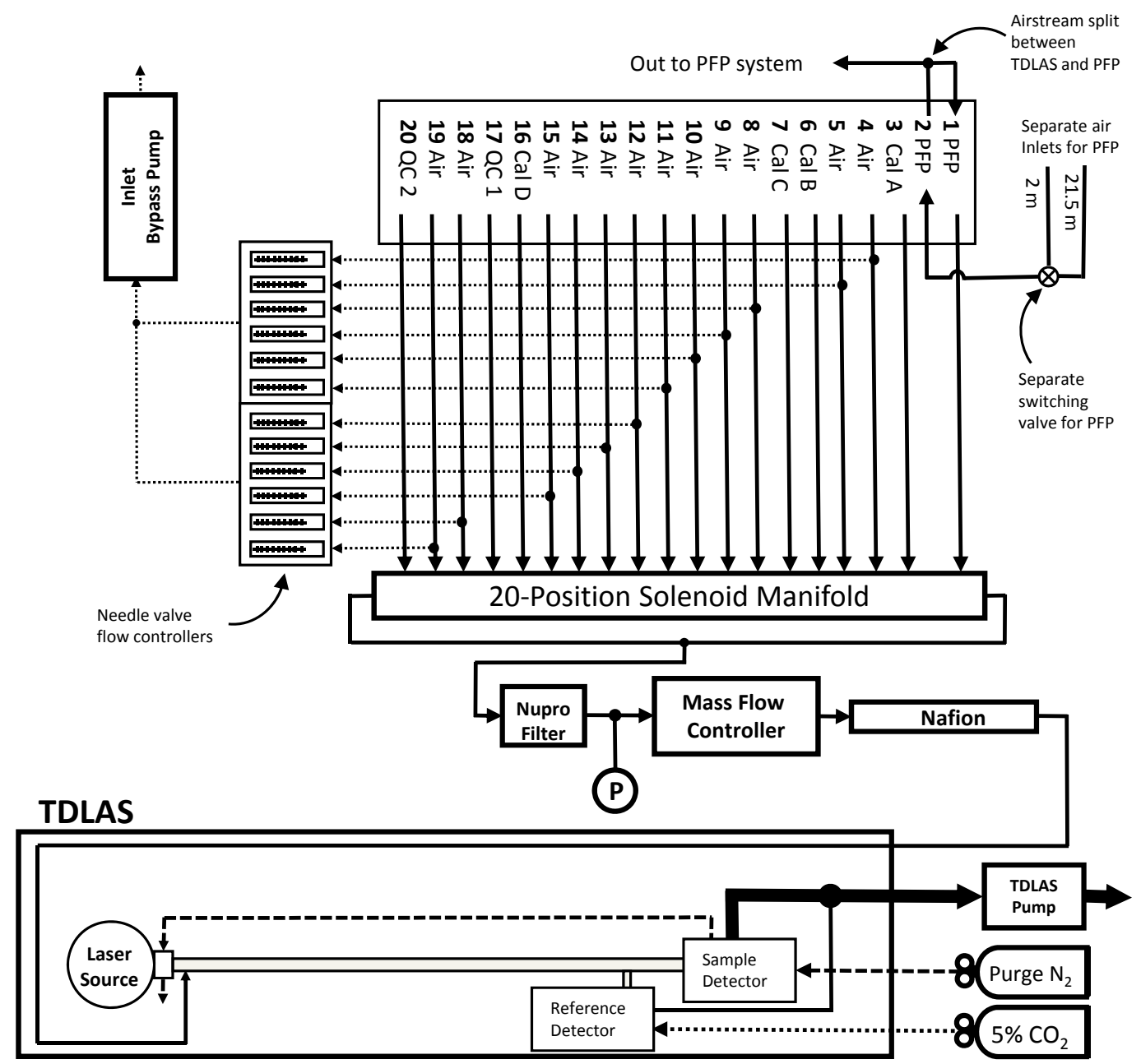

Fig. 1. Schematic view of tunable diode laser absorption spectrometer (TDLAS) sampling system. Air sample inlets (air), portable flask package inlet (PFP), and calibration (cal) and quality control (QC) tank gas pass through a manifold controlled using solenoid valves. Air is filtered, its flow rate controlled using a mass flow controller, and dried (Nafion) before passing into the TDLAS. Air sample lines are continually flushed using a bypass pump at $\sim 1 \mathrm{~L} \mathrm{~min}^{-1}$ (controlled using needle valve flow meters for each line). Not all air sample lines were used in this study.

near $-30 \%$ prior to filling. During routine field operation, four working calibration tanks were used, ranging in $\left[\mathrm{CO}_{2}\right]$ from $\sim 350$ to $\sim 500 \mu \mathrm{mol} \mathrm{mol}^{-1}$ (in $40-50 \mu \mathrm{mol} \mathrm{mol}^{-1}$ increments) and $\delta^{13} \mathrm{C}$ from -8.5 to $-14.5 \%$. Since the TDLAS system measured $\left[{ }^{12} \mathrm{CO}_{2}\right]$ and $\left[{ }^{13} \mathrm{CO}_{2}\right]$ independently, it was not critical that the calibration gases differed in isotope ratio, as ranges in $\left[{ }^{12} \mathrm{CO}_{2}\right]$ and $\left[{ }^{13} \mathrm{CO}_{2}\right]$ observed in environmental samples are driven primarily by the variation in $\left[\mathrm{CO}_{2}\right]$ (Bowling et al., 2005). The measurement of $\left[\mathrm{CO}_{2}\right]$ in field calibration tanks was propagated from five World Meteorological Organization (WMO)-traceable primary or secondary $\mathrm{CO}_{2}$ standards via non-dispersive infrared gas analysis in the laboratory (NDIR, LI-7000, Licor, Inc., Lincoln, Nebraska). The $\delta^{13} \mathrm{C}$ of $\mathrm{CO}_{2}$ in the calibration gases was measured relative to the VPDB scale using isotope ratio mass spectrometry (IRMS, Finnigan MAT DELTAplus, San Jose,
California) at the SIRFER facility. Uncertainty for the calibration tank values was $0.16 \mu \mathrm{mol} \mathrm{mol}^{-1}$ and $0.05 \%$ o (the maximum standard deviation observed for repeated laboratory measurements of all tanks). In the field, calibration tanks were replaced when tank pressures reached $\sim 400$ psi. During the time period of the present study, calibration tanks were changed 21 times (not always in sets of 4 ) and a total of 48 tanks were used.

Having four calibration tanks allowed us to use a fourpoint calibration to calculate ${ }^{12} \mathrm{CO}_{2}$ and ${ }^{13} \mathrm{CO}_{2}$ mole fractions. The relationship between detector signal and mole fraction is non-linear for these instruments, and the TDLAS software features an algorithm to correct for detector nonlinearity. We turned off this feature, choosing instead to account for detector non-linearity by applying a second order polynomial curve fit to the raw data (however this approach 
sacrifices some long-term stability and increases noise). As well as being necessary for a non-linear curve fit, previous experience with these instruments has shown that a one- or two-point calibration (even with the linearity coefficient) was insufficient to achieve desired measurement precision, and that a four-point calibration produced greater measurement precision (Bowling et al., 2005). Mole fractions of ${ }^{12} \mathrm{CO}_{2}$ and ${ }^{13} \mathrm{CO}_{2}$ were calculated relative to WMO standards assuming $99.526 \%$ of the $\mathrm{CO}_{2}$ in a sample consists of the isotopomers ${ }^{12} \mathrm{C}^{16} \mathrm{O}^{16} \mathrm{O}$ or ${ }^{13} \mathrm{C}^{16} \mathrm{O}^{16} \mathrm{O}$ (Hoefs, 1997; Bowling et al., 2003). The $\mathrm{X}_{10}$ of $\left[\mathrm{CO}_{2}\right]$ was calculated as the 10 -s mean of $\left[{ }^{12} \mathrm{CO}_{2}\right]+\left[{ }^{13} \mathrm{CO}_{2}\right]$, while $\mathrm{X}_{10}$ of $\delta^{13} \mathrm{C}$ was calculated as the mean relative to the Vienna PDB scale as:

$\delta^{13} \mathrm{C}=1000 \times\left(\frac{\left[{ }^{13} \mathrm{CO}_{2}\right] /\left[{ }^{12} \mathrm{CO}_{2}\right]}{\mathrm{RPDB}}-1\right), \%$ o

where RPDB is the ${ }^{13} \mathrm{C} /{ }^{12} \mathrm{C}$ of Vienna PDB, and assumed to be 0.01124 (Craig, 1957; Zhang and Li, 1990; Griffis et al., 2004).

Every six hours in the field (00:00, 06:00, 12:00, and 18:00 $\mathrm{h}$ ), two additional tanks, hereafter referred to as quality control (QC) tanks, were measured for $\left[\mathrm{CO}_{2}\right]$ and $\delta^{13} \mathrm{C}$ of $\mathrm{CO}_{2}$. These QC tanks were treated as unknown samples and measured in a 10-min cycle with four working calibration tanks. Field-measured values of QC tanks were then compared to their laboratory-established values for the purposes of defining long-term instrumental accuracy and precision and identifying potential shifts in measurements when calibration tanks were replaced. These QC tanks were measured repeatedly in the laboratory for 8 months (Table 1) prior to their use in the field to assess any potential drift in $\left[\mathrm{CO}_{2}\right]$ and/or $\delta^{13} \mathrm{C}$ over time. While still in use the field, flask samples from the QC tanks were filled on DOY 240, 2007 (23 months into the study) and measured in the laboratory for $\delta^{13} \mathrm{C}$ of $\mathrm{CO}_{2}$. It was not possible to measure $\left[\mathrm{CO}_{2}\right]$ with high accuracy in these samples as the tanks remain in the field and the flask samples collected were too small.

\subsection{Flask sampling}

The sampling design allowed for direct comparison between the University of Utah-based TDLAS measurements, with those made by the National Oceanic and Atmospheric Administration (NOAA) Carbon Cycle Greenhouse Gases (CCGG) Group and the Stable Isotope Laboratory at the Institute of Arctic and Alpine Research (INSTAAR) at the University of Colorado. Flask sampling was conducted in order to provide an independent WMO and VPDB-scale measurement (via these laboratories) for comparison to field TDLAS measurements.

Samples were collected using a portable compressor package (PCP) and portable flask package (PFP) identical to those used by the CCGG program for automated aircraft sampling
Table 1. Repeated measurements of $\mathrm{CO}_{2}$ mole fraction ( $\mu \mathrm{mol}$ $\mathrm{mol}^{-1}$ ) and $\delta^{13} \mathrm{C}(\% \circ)$ of quality control (QC) tanks before and during the first 2 years of field deployment. Each value is the mean of three observations with the standard deviation of the mean in parentheses. Measurements were made in the laboratory using non-dispersive infrared (NDIR) gas analysis for mole fraction and continuous-flow isotope ratio mass spectrometry (IRMS) for $\delta^{13} \mathrm{C}$.

\begin{tabular}{|c|c|c|c|c|}
\hline $\begin{array}{l}\text { Day of Year, } \\
\text { Year }\end{array}$ & Tank $1\left[\mathrm{CO}_{2}\right]$ & Tank $2\left[\mathrm{CO}_{2}\right]$ & Tank $1 \delta^{13} \mathrm{C}$ & Tank $2 \delta^{13} \mathrm{C}$ \\
\hline 302,2004 & $452.18(0.08)$ & $359.86(0.03)$ & $-11.10(0.05)$ & $-8.83(0.04)$ \\
\hline 309,2004 & $452.13(0.08)$ & $359.78(0.08)$ & $-11.14(0.10)$ & $-8.89(0.04)$ \\
\hline 314,2004 & $452.18(0.07)$ & $359.90(0.01)$ & $-11.12(0.03)$ & $-8.82(0.06)$ \\
\hline 321,2004 & $452.19(0.04)$ & $359.82(0.05)$ & $-11.13(0.10)$ & $-8.86(0.10$ \\
\hline 351,2004 & $452.09(0.19)$ & $359.86(0.03)$ & $-11.11(0.06)$ & $-8.92(0.06)$ \\
\hline 18,2005 & $452.16(0.03)$ & $359.81(0.01)$ & $-11.10(0.04)$ & $-8.90(0.03)$ \\
\hline 68,2005 & $452.24(0.01)$ & $359.87(0.01)$ & N/A & $-8.92(0.09)$ \\
\hline 73,2005 & $452.23(0.02)$ & $359.85(0.02)$ & N/A & N/A \\
\hline 147,2005 & $452.21(0.02)$ & $359.91(0.03)$ & $-11.12(0.03)$ & $-8.90(0.05)$ \\
\hline 152,2005 & $452.17(0.03)$ & $359.85(0.02)$ & $-11.09(0.02)$ & $-8.89(0.06)$ \\
\hline 159,2005 & $452.22(0.01)$ & $359.84(0.03)$ & $-11.10(0.04)$ & $-8.93(0.04)$ \\
\hline Mean & 452.18 & 359.85 & -11.11 & -8.89 \\
\hline $240,2007^{*}$ & N/A & N/A & $-10.99(0.07)$ & $-8.72(0.04)$ \\
\hline
\end{tabular}

* These values are the mean of 12 observations where $\delta^{13} \mathrm{C}$ was measured via IRMS and $\mathrm{CO}_{2}$ mole fraction was not measured.

(Tans et al., 1996). Briefly, the PCP consisted of two batterypowered pumps in series. Air entered the PCP via a sampling line and then entered the PFP at a flow rate of about $12 \mathrm{~L} / \mathrm{min}$ (STP) via a transfer line. The PFP consisted of twelve $700 \mathrm{~mL}$ boro-silicate glass flasks, each with two automated Teflon-tipped stopcocks, as well as an on-board computer. The PFPs used at this site were also specially fitted with a manifold on the exit flask valves. This "backmanifold" was kept at the same high pressure as the inside of the flasks in order to minimize permeation of gases through the Teflon-tipped stopcocks (previously observed during laboratory testing). During sampling, the manifold connecting the twelve flasks was flushed with $5 \mathrm{~L}$ of air, then the sample flask was flushed with $20 \mathrm{~L}$ and then pressurized to about $300 \mathrm{kPa}$ absolute. Since February, 2007, the intake lines for the PFP sampling were flushed continuously at $1 \mathrm{~L} / \mathrm{min}$ between sampling using an independent pump. The PCP remained at the site, and the PFPs moved between the field site and laboratories in Boulder, $\mathrm{CO}$. The average time between flask filling and analysis was 18 days for $\mathrm{CO}_{2}$ and 25 days for $\delta^{13} \mathrm{C}$, with maximum storage lengths of 47 and 53 days.

On even-numbered days at $02: 00 \mathrm{~h}$, a single flask was filled with air from an unbuffered tubing inlet located at $2 \mathrm{~m}$ height above the forest floor, and at 14:00 $\mathrm{h}$ a single flask was filled from an unbuffered $21.5 \mathrm{~m}$ inlet. As we show below, the lack of volume-buffering on the sample lines led at times to rapidly changing $\left[\mathrm{CO}_{2}\right]$ during flask collection. Simultaneous TDLAS measurements were made from the inlet tubing while flasks were being filled, although it was not possible to measure during the entire time period of flask sampling 

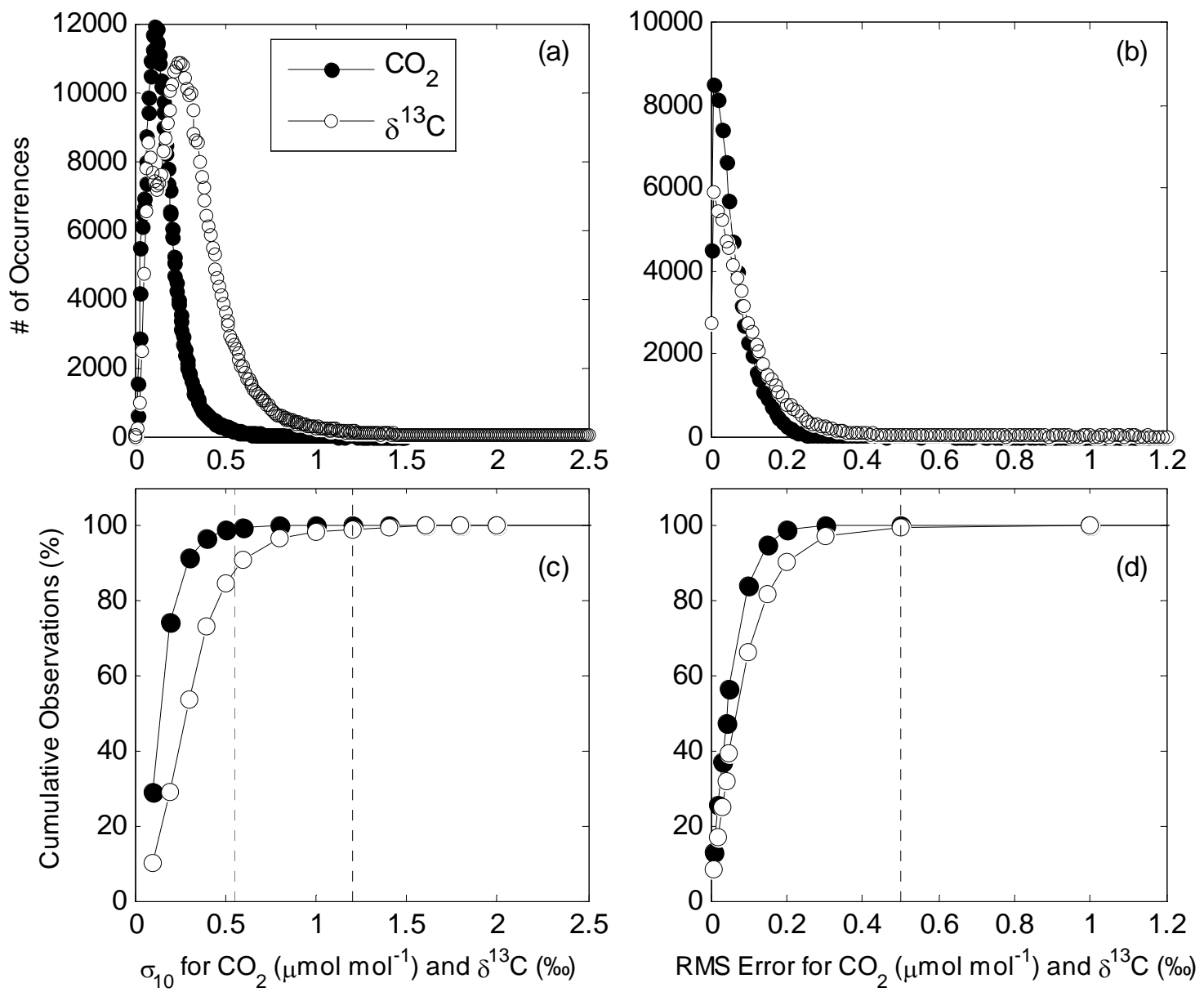

Fig. 2. Comparison of two estimates of TDLAS performance for measurement of the mole fraction and $\delta^{13} \mathrm{C}$ of atmospheric $\mathrm{CO}_{2}$. Panel (a) shows frequency distributions of the standard deviations of the 10 TDLAS measurements (once a second for 6-10s) whose averages constitute a single sample measurement. Panel (b) shows frequency distributions of the root mean square (RMS) error of calibration tank regression fits. Measurements whose standard deviations were greater than $0.55 \mu \mathrm{mol} \mathrm{mol}^{-1}$ for $\left[\mathrm{CO}_{2}\right]$ or $1.2 \%$ for $\delta^{13} \mathrm{C}$ were considered faulty and removed from the final dataset (dashed lines in panel (c)). Measurement cycles whose RMS errors for either $\left[\mathrm{CO}_{2}\right]$ or $\delta^{13} \mathrm{C}$ were greater than $0.5 \mu \mathrm{mol} \mathrm{mol}^{-1}$ or $0.5 \%$ owere similarly omitted (dashed line in panel (d)). These cutoff values resulted in retention of greater than $99 \%$ of the data in each case.

(in order to keep the TDLAS cell pressure stable). This sampling strategy provided a wide variety of $\mathrm{CO}_{2}$ mole fractions and isotope ratios in flask samples for comparison to TDLAS measurements. Such a comparison provided a baseline comparison for accuracy that allowed evaluation of the long-term data quality from the TDLAS relative to independent laboratories.

Flasks were also collected, either manually or using a second PFP, at a nearby alpine tundra site. The site (called NWR or Niwot Ridge) has been used by NOAA CCGG and INSTAAR for decades; the $\mathrm{CO}_{2}$ record began in 1968 and the $\delta^{13} \mathrm{C}$ of $\mathrm{CO}_{2}$ record began in 1990 . The NWR site $\left(40.05^{\circ} \mathrm{N}\right.$ $105.58^{\circ} \mathrm{W} 3423 \mathrm{~m}$ a.s.1.) is located approximately $3 \mathrm{~km}$ to the NW and $373 \mathrm{~m}$ higher in elevation than the subalpine forest where the TDLAS was located. Flask data from NWR are used in this paper to establish the regional and seasonal cycles of $\mathrm{CO}_{2}$ and $\delta^{13} \mathrm{C}$ for comparison with the TDLAS data from the forest.

Analyses of $\delta^{13} \mathrm{C}$ on PFP samples was conducted at the INSTAAR Stable Isotope Lab using a GV IsoPrime (GV Instruments, Manchester, UK) dual inlet isotope ratio mass spectrometer with a custom cryogenic $\mathrm{CO}_{2}$ extraction technique (Vaughn et al., 2004). The normal reproducibility of $\delta^{13} \mathrm{C}$ from cylinders of compressed air on the dual inlet instrument is $0.02 \%$ at $1 \sigma$. Mean reproducibility of PFP samples based on earlier tests $(n=12)$ is $0.01 \%$ for $\delta^{13} \mathrm{C}$ at $1 \sigma$. Tests comparing PFPs and 2.51 NOAA glass flasks filled from the same cylinder of compressed air and analyzed on the same instrument were not statistically different (data not shown). However, in tests comparing PFPs to direct measurements of the cylinders used to fill them, there was a statistically significant difference, showing the PFP's 
to be isotopically lighter by $0.03 \%$ ofor $\delta^{13} \mathrm{C}(p<0.05, n=82)$. Tests comparing sample storage times in PFP flasks did not show any statistical significance between those with short ( $\sim 3$ day) or long ( $\sim 30$ day) storage times (data not shown). The latter storage times are applicable to this study.

\section{Results and discussion}

\subsection{Data processing and quality assurance}

Over the first 2-years of the study there were a total of 101431 10-min measurement periods. This translated to 787495 potential observations (10-min periods and 5 or 9 measurement heights), but after quality control cycles, flask comparisons, low inlets being buried by the snow, and sharing of air sampling manifold time with other instruments, the number of potential observations was actually 526411 over the 2-year period. Additional periods of data loss were due to mechanical and electrical problems (power outages, plumbing malfunctions, loose wires, etc.), or rapid changes in temperature and pressure inside the TDLAS instrument housing. Using temperature measurements, we found that rapid fluctuations in TDLAS sample cell temperature were caused by opening of the door of the shack where the TDLAS was located. Poor data were collected during these periods. After removal of these time periods 427434 observations were left ( $81 \%$ of the total potential observations).

Each reported measurement is the mean of 10 (or at a minimum 6, see below) one-second observations from the TDLAS $\left(\mathrm{X}_{10}\right)$, and each 1 -s value was calculated internally by the instrument as the mean of ten 100-ms values. The standard deviation of the ten $1 \mathrm{~s}$ observations $\left(\sigma_{10}\right)$ is an indication of raw instrumental precision. The standard deviation did not change when either a 15 or 20 s interval was used instead (data not shown) indicating that performance was not improved by increasing the time interval being averaged beyond $10 \mathrm{~s}$. Optimal averaging time for this instrument based on Allen variance is 25-30 s (Bowling et al., 2003), however our selection of inlet heights and flow rates and associated plumbing transients practically limits time averaging to $20 \mathrm{~s}$ maximum.

Post-collection processing of the $10 \mathrm{~s}$ periods resulted in greater instrumental precision (lower $\sigma_{10}$ ) when outliers in raw 1-s output were eliminated. This processing was done by (1) first calculating $\mathrm{X}_{10}$ and $\sigma_{10}$ for a given 10-s sampling period, then (2) any observations greater than one standard deviation from that mean were discarded. Values were discarded starting with the greatest absolute difference from the mean, and continuing up to a maximum of four values. The $\mathrm{X}_{10}$ and $\sigma_{10}$ were then recalculated for the remaining points (hence the number of $1 \mathrm{~s}$ measurements used to calculate the final $\mathrm{X}_{10}$ and $\sigma_{10}$ varies between 6 and 10 for a given measurement). Post-collection processing was applied to the calculated values of $\mathrm{CO}_{2}$ and $\delta^{13} \mathrm{C}$, rather than the measured values of $\left[{ }^{12} \mathrm{CO}_{2}\right]$ and $\left[{ }^{13} \mathrm{CO}_{2}\right]$. A frequency distribution of $\sigma_{10}$ for the two-year period is shown in Fig. 2a. The means and standard deviations for the distributions shown were $0.16 \pm 0.10 \mu \mathrm{mol} \mathrm{mol}^{-1}$ and $0.33 \pm 0.20 \%$ of $\left[\mathrm{CO}_{2}\right]$ and $\delta^{13} \mathrm{C}$ respectively (see also Table 3 for an indication of how these vary with some identified problems). These values indicate the inherent instrumental variability in measuring these quantities, independent of calibration method. They also reflect uncertainty associated with the sampling system (plumbing, rapid changes in $\left[\mathrm{CO}_{2}\right]$, etc.).

The root mean squared (RMS) error of the calibration curve fit measured in each cycle was previously reported by Bowling et al. (2005) as an estimate of instrument performance. The RMS error was calculated separately for $\mathrm{CO}_{2}$ and $\delta^{13} \mathrm{C}$ as:

RMSerror $=\sqrt{\frac{\sum(\text { actual }- \text { observed })^{2}}{n}}$

where actual $\left[\mathrm{CO}_{2}\right]$ and $\delta^{13} \mathrm{C}$ were laboratory-established values for each calibration tank, observed values were measured in the field for each tank during a given 10-min cycle, and $n$ is the total number of tanks $(n=4)$. Note that this is not a fully objective measure of instrument performance since the four calibration tanks are used to generate the "observed" values for each tank. The observed values for each tank are thus likely to have smaller error than the measurement of an unknown air sample would. Thus, a large RMS tank error is a valid metric for poor (but not good) instrument performance, and the RMS tank error was used in this fashion. The distribution of RMS tank errors for the entire dataset is shown in Fig. 2b. The mean and standard deviations of these distributions were $0.06 \pm 0.06 \mu \mathrm{mol} \mathrm{mol}^{-1} \mathrm{CO}_{2}$ and $0.09 \pm 0.09 \%$ o $\delta^{13} \mathrm{C}$ (also see Table 3 ).

Criteria were developed to remove unusually poor data from the final dataset. Exact values of the thresholds (described below) are arbitrary and likely to be different for different TDLAS instruments and different applications. Hopefully these can serve as a guide for other researchers to develop their own criteria for data quality. If a shift occurred when an unknown air sample was being analyzed, only that sample was affected; however if a shift occurred when a calibration tank was being measured, all measurements for the given $10 \mathrm{~min}$ measurement cycle were affected. For $\left[\mathrm{CO}_{2}\right]$, we removed any observation (unknown air samples) where $\sigma_{10}$ was greater than $0.55 \mu \mathrm{mol} \mathrm{mol}^{-1}$. A total of $0.9 \%$ of the total observations failed this criterion (the cumulative distribution is shown in Fig. 2c). For $\delta^{13} \mathrm{C}$, any observations whose $\sigma_{10}$ was greater than $1.2 \%$ were removed, and $1.0 \%$ of observations failed this criterion (Fig. 2c). We also used RMS tank error values to remove all data from a given 10min measurement cycle when performance was poor. For $\left[\mathrm{CO}_{2}\right]$ and $\delta^{13} \mathrm{C}$, any 10-min cycle whose RMS error for either $\left[\mathrm{CO}_{2}\right]$ or $\delta^{13} \mathrm{C}$ was greater than $0.50\left(\mu \mathrm{mol} \mathrm{mol}{ }^{-1}\right.$ or \%o) was removed from the final dataset. If the $\left[\mathrm{CO}_{2}\right]$ 
Table 2. Mean mole fraction and $\delta^{13} \mathrm{C}$ of $\mathrm{CO}_{2}$ measured on quality control (QC) tanks over the first two years of the study. These tanks were prepared and measured identically to field calibration tanks, but were not used for any calibrations. Measured values are those taken from measurements in the field every six hours. Actual values are those determined in the laboratory using non-dispersive infrared gas analysis for mole fraction and isotope ratio mass spectrometry for $\delta^{13} \mathrm{C}$. Numbers in parentheses are the standard deviation of the mean ( $n=2908$ for the field).

\begin{tabular}{lrr}
\hline & {$\left[\mathrm{CO}_{2}\right]\left(\mu \mathrm{mol} \mathrm{mol}^{-1}\right)$} & $\delta^{13} \mathrm{C}(\%)$ \\
\hline Tank 1 (measured in field) & $452.13(0.17)$ & $-10.95(0.32)$ \\
Tank 1 (actual) & $452.17(0.07)$ & $-11.12(0.06)$ \\
Tanks 1 (actual - measured) & $0.04(0.18)$ & $-0.17(0.33)$ \\
& & \\
Tank 2 (measured in field) & $359.82(0.15)$ & $-8.75(0.33)$ \\
Tank 2 (actual) & $359.84(0.06)$ & $-8.89(0.06)$ \\
Tanks 2 (actual - measured) & $0.02(0.16)$ & $-0.14(0.34)$ \\
\hline
\end{tabular}

RMS errors failed the acceptance criteria, the corresponding $\delta^{13} \mathrm{C}$ data were also removed (and vice-versa). For $\left[\mathrm{CO}_{2}\right]$ and $\delta^{13} \mathrm{C}, 0.05$ and $0.04 \%$ of 10 -min cycles failed these criteria (Fig. 2d). Overall, $98.8 \%$ of the total possible $\left[\mathrm{CO}_{2}\right]$ observations during the first two years of the study $(n=422305)$ were kept after applying these quality assurance cutoffs, and $98.6 \%(n=421450)$ of the total $\delta^{13} \mathrm{C}$ observations were retained.

\subsection{Quality control and performance}

Analysis of quality control (QC) tanks allowed for a consistent assessment of instrument performance as applied to unknown air samples. There were 48 calibration tanks used for the TDLAS since our study began, but the two QC tanks were not changed. Field measurements for $\left[\mathrm{CO}_{2}\right]$ and $\delta^{13} \mathrm{C}$ for both QC tanks over the first two years of the study are shown in the top four panels of Fig. 3 and in Tables 1 to 3. The mean difference between actual and measured values for each tank was $0.04 \pm 0.18 \mu \mathrm{mol} \mathrm{mol}^{-1}$ and $-0.17 \pm 0.33 \%$ o for tank 1 , and $0.02 \pm 0.16 \mu \mathrm{mol} \mathrm{mol}^{-1}$ and $-0.14 \pm 0.4 \%$ ofor tank 2 (Table 2).

The standard deviation of actual-minus-measured values of the QC tanks is a useful measure of field performance. Over the entire 2.44-year period, these standard deviations were $0.19 \mu \mathrm{mol} \mathrm{mol}^{-1}$ and 0.31 to $0.33 \%$ (Table 3). The TGA manufacturer reports the calibrated precision of this instrument as $0.05 \mu \mathrm{mol} \mathrm{mol}^{-1}$ and $0.1 \%$ (http://www. campbellsci.com/documents/manuals/tga100a-ov.pdf). Two problems were identified that mildly affected instrument performance during the first part of the study (days -108 to 494), including an incorrect software setting ("moving average time") and unusually low detector signals (perhaps caused by poor parameter tuning or optical alignment). During this period the $\delta^{13} \mathrm{C}$ performance was a bit noisier ( 0.36 to $0.37 \%$, Table 3). A third problem led to a bias in QC
Table 3. Different measures of TDLAS performance. The $\sigma_{10}$ value is the mean of all $\sigma_{10}$ values for $\left[\mathrm{CO}_{2}\right]\left(\mu \mathrm{mol} \mathrm{mol}^{-1}\right)$ or $\delta^{13} \mathrm{C}(\%)$, and represents the precision of the raw measurement without calibration. The RMS tank error is the mean for all measurement cycles for $\left[\mathrm{CO}_{2}\right]$ and $\delta^{13} \mathrm{C}$, and is useful to exclude bad periods only. The values for QC tanks are the standard deviations of all differences (actual - measured) for $\left[\mathrm{CO}_{2}\right]$ and $\delta^{13} \mathrm{C}$ for each tank, and are used to assess long-term accuracy (Table 2) and precision (here). The PFP comparison is the mean or standard deviation of the difference between TDLAS and PFP values (TDLAS - PFP), and is used to assess the long-term accuracy and precision, as well as an independent scale verification. Data are shown for the entire 2.44yr study, and for subsets of that period indicated by DOY relative to 2006. The small number of PFP samples during the "ideal" time period results because we ended the direct comparison sampling procedure. This change was made for logistical reasons, unfortunately before some of the TDLAS problems listed in the table were identified.

\begin{tabular}{|c|c|c|c|c|c|c|}
\hline & $\sigma_{10}$ & $\begin{array}{r}\text { RMS tank } \\
\text { error }\end{array}$ & $\begin{array}{r}\mathrm{QC} \\
\operatorname{tank} 1\end{array}$ & $\begin{array}{r}\mathrm{QC} \\
\operatorname{tank} 2\end{array}$ & $\begin{array}{r}\text { PFP } \\
\text { mean }\end{array}$ & $\begin{array}{r}\text { PFP } \\
\text { SD }\end{array}$ \\
\hline \multicolumn{7}{|c|}{ days -108 to 783 (all data) } \\
\hline$\left[\mathrm{CO}_{2}\right]$ & 0.14 & 0.06 & 0.19 & 0.19 & 0.47 & 1.20 \\
\hline$n$ for $\mathrm{CO}_{2}$ & 527,337 & 80,851 & 2315 & 2271 & 232 & 232 \\
\hline$\delta^{13} \mathrm{C}$ & 0.29 & 0.09 & 0.31 & 0.33 & 0.00 & 0.45 \\
\hline$n$ for $\delta^{13} \mathrm{C}$ & 527337 & 80851 & 2318 & 2254 & 277 & 277 \\
\hline \multicolumn{7}{|c|}{ days -108 to 494 (wrong moving average and/or low detector signals) } \\
\hline$\left[\mathrm{CO}_{2}\right]$ & 0.17 & 0.06 & 0.17 & 0.15 & 0.57 & 1.17 \\
\hline$n$ for $\mathrm{CO}_{2}$ & 354155 & 59197 & 1502 & 1479 & 190 & 190 \\
\hline$\delta^{13} \mathrm{C}$ & 0.37 & 0.10 & 0.36 & 0.37 & 0.00 & 0.41 \\
\hline$n$ for $\delta^{13} \mathrm{C}$ & 354155 & 59197 & 1508 & 1464 & 217 & 217 \\
\hline \multicolumn{7}{|c|}{ days 520 to 650 (excessive internal temperature) } \\
\hline$\left[\mathrm{CO}_{2}\right]$ & 0.10 & 0.06 & 0.21 & 0.24 & -0.04 & 1.25 \\
\hline$n$ for $\mathrm{CO}_{2}$ & 84563 & 9886 & 343 & 322 & 28 & 28 \\
\hline$\delta^{13} \mathrm{C}$ & 0.12 & 0.08 & 0.25 & 0.29 & -0.02 & 0.64 \\
\hline$n$ for $\delta^{13} \mathrm{C}$ & 84563 & 9886 & 341 & 321 & 47 & 47 \\
\hline \multicolumn{7}{|c|}{ days 650 to 783 (all problems fixed, ideal performance) } \\
\hline$\left[\mathrm{CO}_{2}\right]$ & 0.06 & 0.06 & 0.24 & 0.20 & -0.07 & 0.43 \\
\hline$n$ for $\mathrm{CO}_{2}$ & 80323 & 10385 & 408 & 408 & 3 & 3 \\
\hline$\delta^{13} \mathrm{C}$ & 0.12 & 0.05 & 0.17 & 0.17 & -0.01 & 0.02 \\
\hline$n$ for $\delta^{13} \mathrm{C}$ & 80323 & 10385 & 408 & 408 & 3 & 3 \\
\hline
\end{tabular}

tank measurement during days 520 to 650 (Fig. 3 and Table 3). This was apparent as a small bias (tenths of ppm or \%o) in QC tank values in Fig. 3. This was caused by overheating of the TGA instrument enclosure during the hottest days of summer 2007, a problem which has been corrected by moving a pump outside the shack. The small $\left(<0.5 \mu \mathrm{mol} \mathrm{mol}^{-1}\right)$ bias visible in Fig. 3 beginning day 520 reflects a temperature-related diurnal change in the measured values for each tank, especially for $\mathrm{CO}_{2}$.

The noisier signals during the above time periods negatively affected instrument performance (Table 3). After all three problems were fixed (days 650 to 783 ), the standard deviations of QC tank measurements were 0.2 to $0.24 \mu \mathrm{mol} \mathrm{mol}^{-1}$ and $0.17 \%$. The RMS errors during 

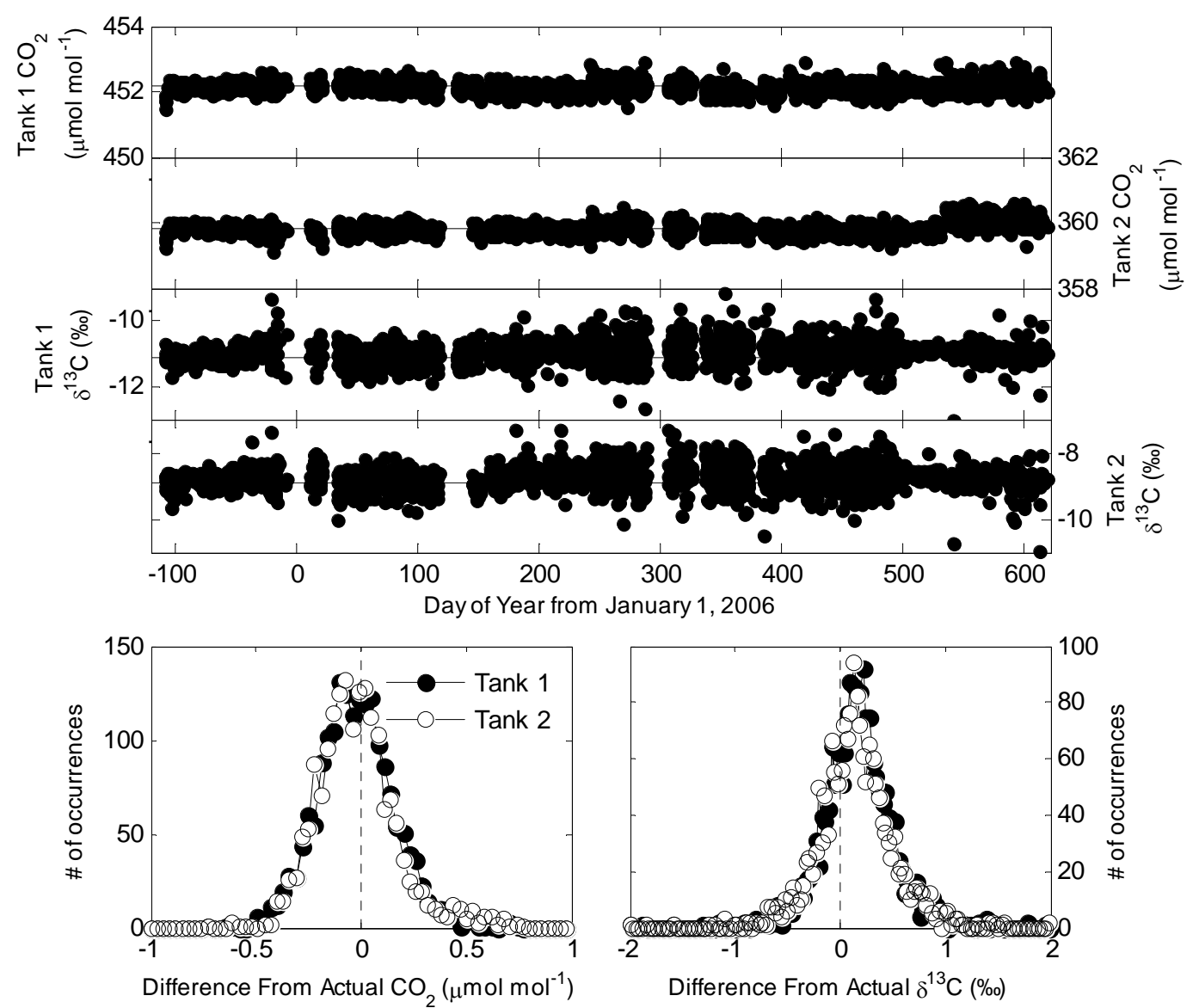

Fig. 3. Measured values of $\left[\mathrm{CO}_{2}\right]$ and $\delta^{13} \mathrm{C}$ for two quality control (QC) tanks for the 2-year study period. The four upper panels show $\left[\mathrm{CO}_{2}\right]$ and $\delta^{13} \mathrm{C}$ for each of the two QC tanks relative to 1 January 2006. Solid horizontal lines represent the actual (laboratory-established) values of $\left[\mathrm{CO}_{2}\right]$ and $\delta^{13} \mathrm{C}$ for each tank (see Table 1). Frequency distributions of the actual - measured values of $\left[\mathrm{CO}_{2}\right]$ and $\delta^{13} \mathrm{C}$ for each tank are shown in the bottom two panels $(n=2908)$. The vertical dashed lines provide a reference for the 0 difference. The mean and standard deviations for each of these relationships are shown in Table 1.

this optimal time period were $0.06 \mu \mathrm{mol} \mathrm{mol}^{-1}$ and $0.05 \%$, which correspond well to those reported in our preliminary study (Bowling et al., 2005) and the manufacturer's specifications.

Measured $\delta^{13} \mathrm{C}$ for both QC tanks was less negative than the actual tank values (Table 2). Although the difference was less than the standard deviation of the measurements, this suggests that a real isotopic measurement bias may exist. Long-term drift or offset in the $\delta^{13} \mathrm{C}$ of the QC tanks (rather than the instrument) is a possible explanation for the observed difference between actual and observed $\delta^{13} \mathrm{C}$, but there does not appear to be strong time-dependency in the measured QC tank values. Multiple measurements (using NDIR and IRMS) of these tanks were made for 319 days prior to their deployment in the field, and one set of measurements (using IRMS only) was made 714 days after deployment (Table 1). Prior to the start of TDLAS measurements in the field, the mean measured values for $\left[\mathrm{CO}_{2}\right]$ and $\delta^{13} \mathrm{C}$ for both tanks fell within $0.01 \mu \mathrm{mol} \mathrm{mol}^{-1}$ and $0.01 \%$ o of the actual value (Table 1). For this 222-day period, there did not appear to be any drift in $\delta^{13} \mathrm{C}$ of QC tanks over time. However, after 714 days in the field, the $\delta^{13} \mathrm{C}$ values of air collected in flasks from the QC tanks and analyzed via IRMS show shifts (of $0.13 \%$ o for tank 1 and $0.17 \%$ o for tank 2 ) relative to their previously established values (Table 1). If we substitute these new QC $\delta^{13} \mathrm{C}$ values for the actual values reported in Table 2, the actual-minus-measured $\delta^{13} \mathrm{C}$ for tank 1 changes to $-0.04 \pm 0.33 \%$, and $0.02 \pm 0.33 \%$ o for tank 2 (the uncertainties for each measurement were added). This suggests that there may indeed have been systematic offsets or drifts in the QC tanks, a possibility with any tanks that remain in use for extended periods of time (years). Based on these results, we recommend periodic re-assessment of any calibration or quality control tanks deployed in the field for extended periods of time.

A summary of the various approaches for estimating the precision of our TDLAS instrument are shown in Table 3. Previous biosphere-atmosphere exchange studies employing 

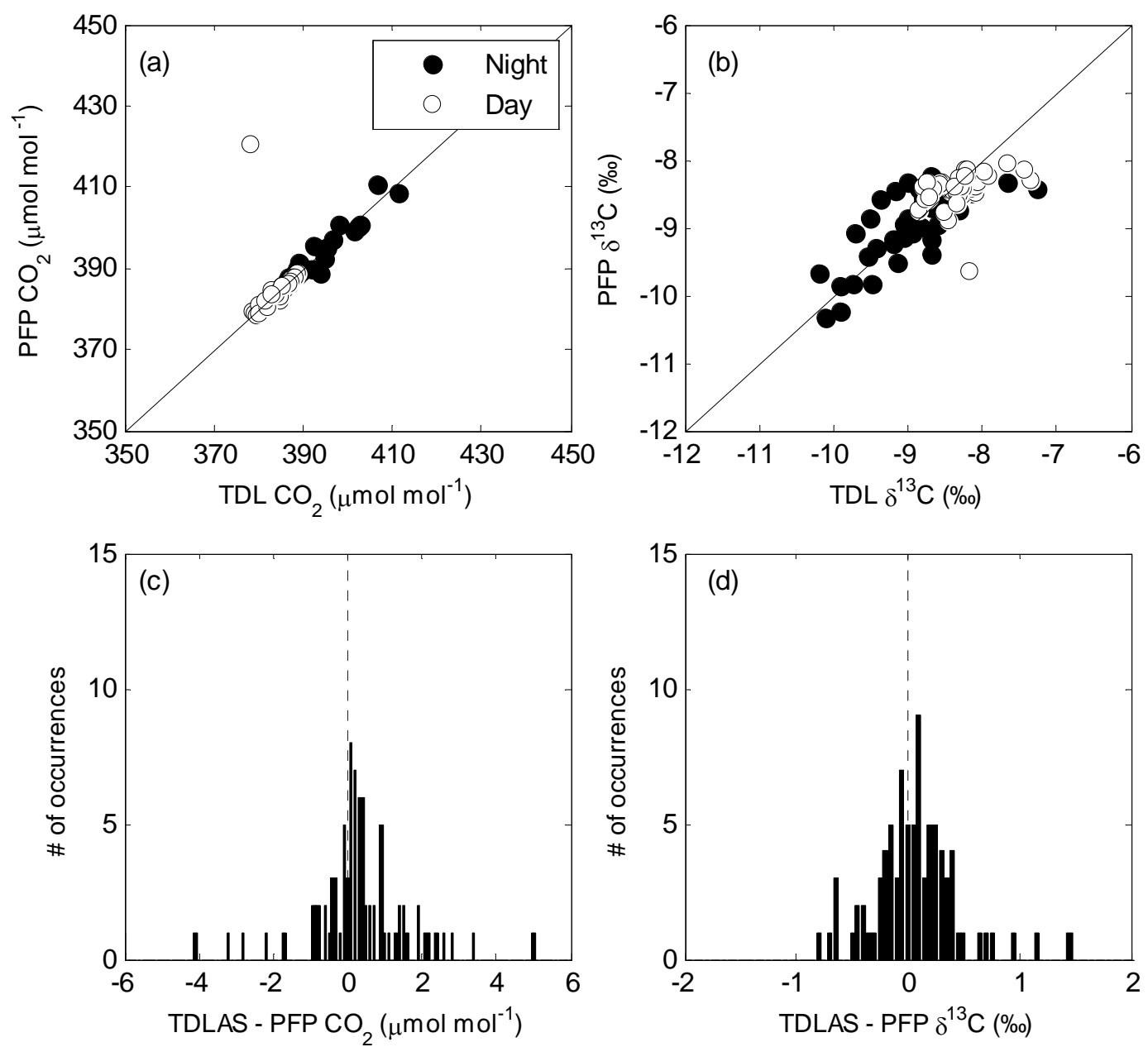

Fig. 4. Comparison of measurements of $\left[\mathrm{CO}_{2}\right]$ and $\delta{ }^{13} \mathrm{C}$ of forest air made by TDLAS with those made by automated flask collection (via portable flask package, PFP). Comparisons of TDLAS and PFP measurements made during daytime (at $21.5 \mathrm{~m}$ height) and at night ( $2 \mathrm{~m}$ height) are shown for $\mathrm{CO}_{2}$ (a) and $\delta^{13} \mathrm{C}(\mathbf{b})$. Frequency distributions of the difference between the two (TDLAS - PFP) are shown for CO 2 (c) and $\delta^{13} \mathrm{C}(\mathbf{d})$. All data are shown.

TDLAS instruments have reported estimates of precision ranging from 0.03 to $0.15 \mu \mathrm{mol} \mathrm{mol}^{-1}$ for $\mathrm{CO}_{2}$ and from 0.03 to $0.15 \%$ or $\delta^{13} \mathrm{C}$ (Bowling et al., 2003, 2005, 2007b; Griffis et al., 2004; Pataki et al., 2006; Zhang et al., 2006). For each of these studies, estimates of precision were calculated using different methods and direct comparison of precision from different studies is not very informative. An additional point to consider is that some groups (Griffis et al., 2005b; Barbour et al., 2007a) use a single laser to measure all three stable isotopomers $\left({ }^{12} \mathrm{C}^{16} \mathrm{O}^{16} \mathrm{O}\right.$, ${ }^{13} \mathrm{C}^{16} \mathrm{O}^{16} \mathrm{O}$, and ${ }^{12} \mathrm{C}^{18} \mathrm{O}^{16} \mathrm{O}$ ). The manufacturer says that the expected precision is worse by roughly a factor of three for these instruments due to the weaker absorption at these lines (http://www.campbellsci.com/documents/ manuals/tga100a-ov.pdf).

Studies by Bowling et al. (2005) and Pataki et al. (2006) used the RMS tank error of calibration regressions as an estimate of precision. As stated previously, the RMS tank error is not an objective measure of precision and should only be used as an indicator of poor performance. The $\sigma_{10}$ provides a better estimate of the instrumental precision, as well as additional uncertainty associated with the sampling system (such as plumbing transients). While $\sigma_{10}$ can be calculated for each unknown air sample, $\sigma_{10}$ does not provide an estimate of errors associated with calibration. We recommend that long-term precision for TDLAS studies be evaluated by regular measurement of QC tanks which are treated as unknowns, as we have done here. This approach provides the most comprehensive assessment of long-term performance and accounts for the greatest number of possible sources of error. Based on this analysis, we conclude that our measurement system shows no bias for $\mathrm{CO}_{2}$ but may have a small bias (of order $0.2 \%$ ) for $\delta^{13} \mathrm{C}$, although the re-analysis of the QC tanks indicates this may be an artifact of shifts in the QC tanks (Tables 1 and 2). We estimate our long-term precision to be $0.2 \mu \mathrm{mol} \mathrm{mol}^{-1} \mathrm{CO}_{2}$ and $0.2 \% \circ \delta^{13} \mathrm{C}$ under ideal 
conditions, and $0.2 \mu \mathrm{mol} \mathrm{mol}^{-1} \mathrm{CO}_{2}$ and $0.35 \% \circ \delta^{13} \mathrm{C}$ under all conditions (Tables 2 and 3 ).

\subsection{Flask comparison}

Comparison of TDLAS measurements with flask samples collected and analyzed separately by a NOAA-CCGG portable flask package (PFP) provide an independent assessment of accuracy, and allow evaluation of the long-term data quality from the TDLAS. A previous comparison between NOAA air samples (not collected using a PFP) analyzed by both NOAA/INSTAAR and an Australian laboratory (CSIRO) found differences of roughly $0.2 \mu \mathrm{mol} \mathrm{mol}^{-1}$ and $0.02 \%$ for $\left[\mathrm{CO}_{2}\right]$ and $\delta^{13} \mathrm{C}$ respectively between the two (Masarie et al., 2001). This suggests a lower limit for comparisons between different laboratories measuring the same air with very similar techniques. Thus, we might reasonably expect poorer agreement when both the collection method (flask and in situ) and analysis method (IRMS and TDLAS) are different. The comparisons between PFP and TDLAS $\left[\mathrm{CO}_{2}\right]$ and $\delta^{13} \mathrm{C}$ are shown in Fig. $4 \mathrm{a}$ and $4 \mathrm{~b}$. Values for $\left[\mathrm{CO}_{2}\right]$ ranged from 374 to $406 \mu \mathrm{mol} \mathrm{mol}^{-1}$ during the day at $21.5 \mathrm{~m}$, and from 381 to $412 \mu \mathrm{mol} \mathrm{mol}^{-1}$ during the night at $2 \mathrm{~m}$. Measurements from both PFP and TDLAS showed relatively good agreement with a 1:1 relationship for both day and night sampling. The difference (TDLAS-PFP) during the first two years had a mean value of $0.48 \pm 0.71 \mu \mathrm{mol} \mathrm{mol}^{-1}$ for $\left[\mathrm{CO}_{2}\right]$, and is a bit larger than that observed for our QC tanks (but is still within one standard deviation of no difference). Part of this bias may result from a known $0.1-0.3 \mu \mathrm{mol} \mathrm{mol}^{-1}$ (low) bias in the PFP measurements (data not shown).

Observed PFP flask values for $\delta^{13} \mathrm{C}$ ranged from -9.6 to $-8.0 \%$ during the day and from -10.2 to $-8.0 \%$ at night. The observed mean difference between TDLAS and PFP for $\delta^{13} \mathrm{C}$ was $0.01 \pm 0.45 \%$ o $(n=277$, Table 3$)$. This mean observed difference was better than that observed for our QC tanks, but had a larger standard deviation. However, for $\delta^{13} \mathrm{C}$ values greater than $-8.25 \%$ the mean TDLAS-PFP difference was $-0.09(n=38)$ and for values less than $-8.75 \%$, the mean difference was $0.08(n=68)$. It is noteworthy that the range of best agreement ( -8.25 to $-8.75 \%$; mean difference $=0.02 ; n=172$ ) occurred in the range where the calibration standards for both the TDLAS and the IRMS were best defined. This is also the $\delta^{13} \mathrm{C}$ range typical for midafternoon samples, where atmospheric variability in $\delta^{13} \mathrm{C}$ is lowest. Frequency distributions for $\left[\mathrm{CO}_{2}\right]$ and $\delta^{13} \mathrm{C}$ of (TDLAS-PFP) are shown in Fig. 4c and 4d.

The large standard deviations observed for mean TDLASPFP $\left[\mathrm{CO}_{2}\right]$ and $\delta^{13} \mathrm{C}$ are likely due to the way in which air was sampled. By examining $\sigma_{10}$ of TDLAS data, we found that poor measurement comparisons with the PFP occurred when $\left[\mathrm{CO}_{2}\right]$ was changing rapidly (primarily at night, data not shown). This may be due to the fact that inlet lines were not passed through buffer volumes, so larger short-

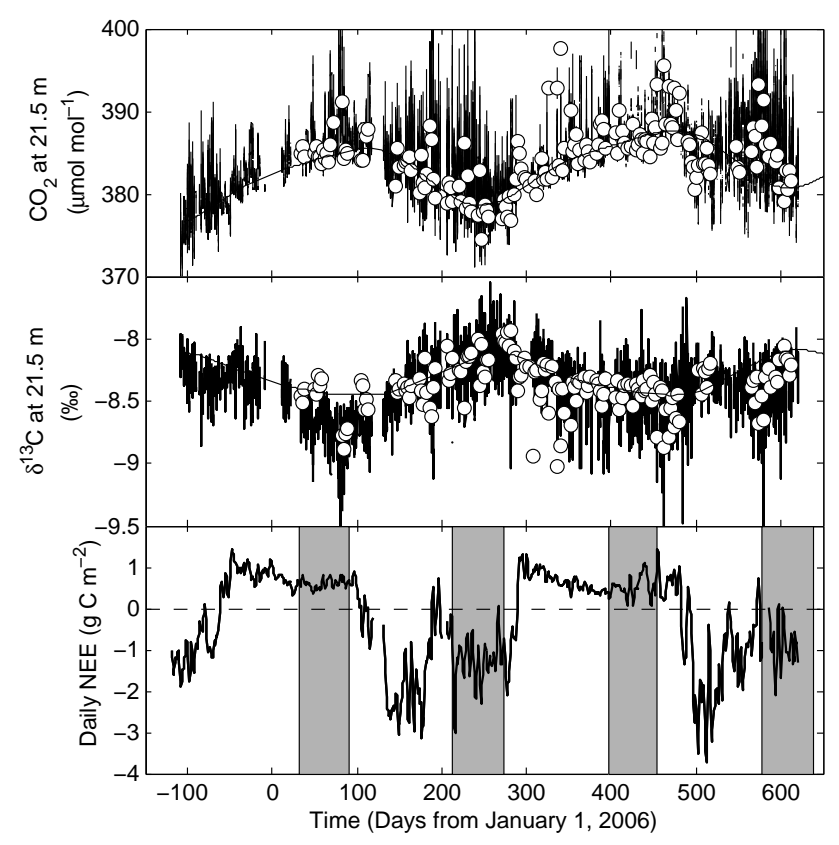

Fig. 5. $\left[\mathrm{CO}_{2}\right]$ and $\delta^{13} \mathrm{C}$ measured by TDLAS at $21.5 \mathrm{~m}$ height (solid line) from 2005 through 2007. Open symbols represent PFP flask samples collected at the same height at 14:00 h. Data from the NOAA CCGG flask network from a nearby alpine tundra site (NWR, approximately $3 \mathrm{~km}$ away and $373 \mathrm{~m}$ higher in elevation) are shown for comparison (smoothed line). Daily net ecosystem exchange (NEE) of $\mathrm{CO}_{2}$ measured at the AmeriFlux tower is shown in the bottom panel for comparison. For NEE, negative numbers indicate net uptake of $\mathrm{CO}_{2}$ by the forest. Shaded regions denote the time periods displayed in Fig. 6.

term variations in $\left[\mathrm{CO}_{2}\right]$ and $\delta^{13} \mathrm{C}$ influenced the variability seen in TDLAS measurements. This may also be due to the fact that PFP measurements were actually integrated over a longer time period (105s) than those from the TDLAS (a $10 \mathrm{~s}$ sub-sample of that $105 \mathrm{~s}$ ). Regardless, these relatively small differences between TDLAS and PFP measurements suggest that the TDLAS is capable of measuring $\left[\mathrm{CO}_{2}\right]$ and $\delta^{13} \mathrm{C}$ accurately within our stated precision $\left(0.2 \mu \mathrm{mol} \mathrm{mol}^{-1}\right.$ $\mathrm{CO}_{2}$ and 0.2 to $0.35 \%$ o $\delta^{13} \mathrm{C}$ ).

\subsection{Seasonal differences in $\delta^{13} \mathrm{C}$ versus $\left[\mathrm{CO}_{2}\right]$}

The relatively short measurement time and field-capable operation of TDLAS instruments provides greater temporal and spatial resolution of $\left[\mathrm{CO}_{2}\right]$ and $\delta^{13} \mathrm{C}$ of $\mathrm{CO}_{2}$ than flask-based techniques (Ogee et al., 2003; Knohl and Buchmann, 2005; Knohl et al., 2005; Mortazavi et al., 2005, 2006). Observation of seasonal variation in the mole fraction and isotopic composition of atmospheric $\mathrm{CO}_{2}$ is an obvious application that would benefit from increased temporal resolution (Lai et al., 2005, 2006). Comparisons between flask and TDLAS-based time series are shown in Fig. 5. Both PFP flask and TDLAS measurements show strong seasonal 

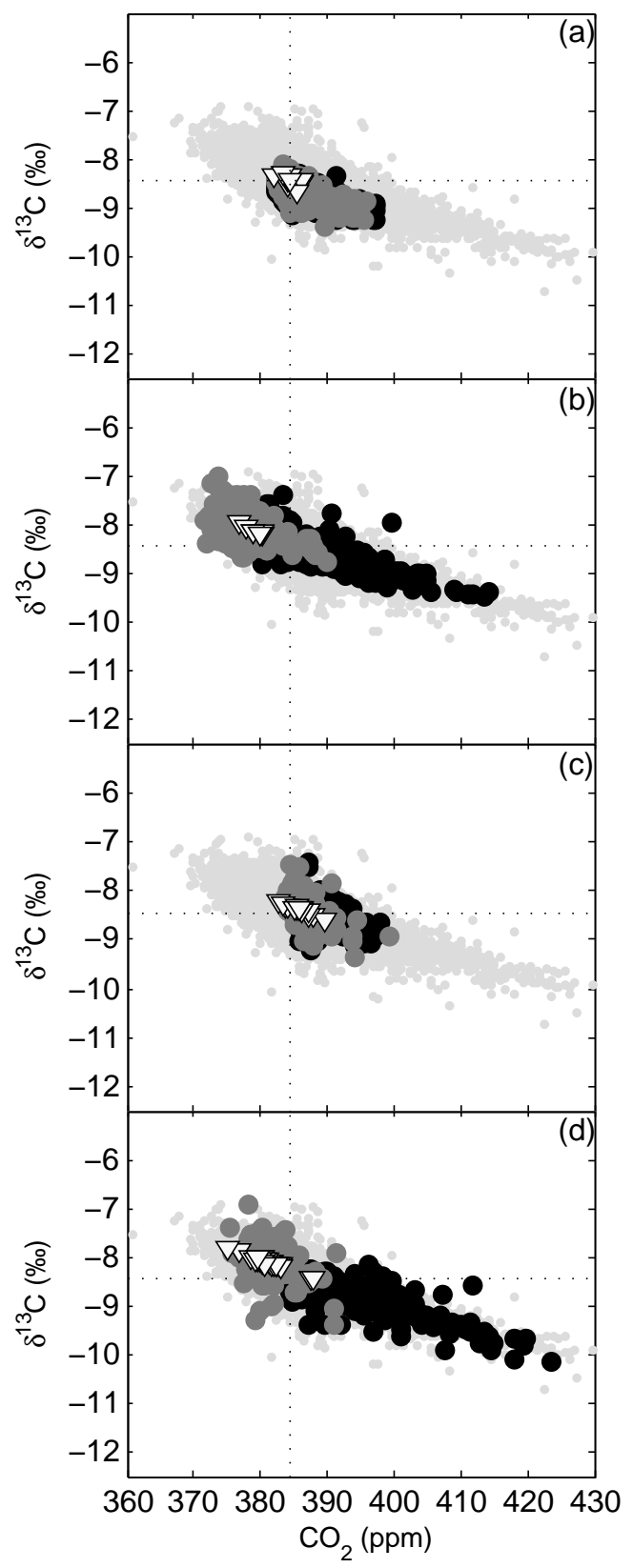

Fig. 6. Seasonal and diurnal variation in $\left[\mathrm{CO}_{2}\right]$ and $\delta^{13} \mathrm{C}$ at $11 \mathrm{~m}$ height at Niwot Ridge during: (a) March-April 2006 (days 32 to 90), (b) August-September 2006 (days 213 to 273), (c) MarchApril 2007 (days 397 to 455), and (d) August-September 2007 (days 578 to 638). These time periods displayed correspond to the shaded regions in the bottom panel of Fig. 5. Black circles show night periods, and gray circles show daytime periods, with light gray symbols showing all the data from panels (a) and (b) in Fig. 5. Triangles are samples from the NOAA CCGG flask network from a nearby alpine tundra site (NWR, approximately $3 \mathrm{~km}$ away and $500 \mathrm{~m}$ higher in elevation). Dotted lines represent mean $\left[\mathrm{CO}_{2}\right]$ and $\delta^{13} \mathrm{C}$ for NWR samples in panel (a). cycles for $\left[\mathrm{CO}_{2}\right]$ and $\delta^{13} \mathrm{C}$ that are similar to those collected from the alpine tundra site (NWR) (smoothed line in Fig. 5). In general, $\left[\mathrm{CO}_{2}\right]$ increased and $\delta^{13} \mathrm{C}$ decreased in the fall and winter as respiratory processes dominated, while $\left[\mathrm{CO}_{2}\right]$ decreased and $\delta^{13} \mathrm{C}$ increased during the growing season (spring and summer) when photosynthesis dominated. The bottom panel in Fig. 5 shows the net ecosystem exchange of $\mathrm{CO}_{2}$ during these two years - periods of net carbon release (positive values) were apparent during fall and winter, and net carbon uptake (negative values) occurred in the spring and summer. The seasonal cycle of $\delta^{13} \mathrm{C}$ at the regionalscale is roughly $0.5 \%$ (Fig. 5). Even though the TDLAS precision for $\delta^{13} \mathrm{C}$ is $0.2 \%$ at best, the seasonal cycle was clearly observed. In addition, TDLAS measurements (from the $21.5 \mathrm{~m}$ sampling height which is $10 \mathrm{~m}$ above the forest canopy) show evidence of significant excursions from the NWR baseline (smoothed line) due to diurnal changes in respiration (year-round) and photosynthesis (growing season) of the local forest (Fig. 5). At midwinter (near days 80 or 430), $\mathrm{CO}_{2}$ at $21.5 \mathrm{~m}$ height was up to $20 \mu \mathrm{mol} \mathrm{mol}^{-1}$ higher and $\delta^{13} \mathrm{C}$ was $1 \%$ more negative than the NWR baseline. During peak summer daytime periods (near days 260 or 620 ), $\mathrm{CO}_{2}$ at $21.5 \mathrm{~m}$ was nearly $10 \mu \mathrm{mol} \mathrm{mol}^{-1}$ lower and $\delta^{13} \mathrm{C}$ was $0.3-$ $0.4 \%$ more enriched than the NWR baseline due to net photosynthesis of the local forest canopy. Summer night periods showed a strong respiratory forest influence with higher $\mathrm{CO}_{2}$ and more depleted $\delta^{13} \mathrm{C}$ than at NWR. Note that Fig. 5 shows the variability in the air $10 \mathrm{~m}$ above the vegetation canopy. The influence of respiration and photosynthesis are much stronger within and below the forest canopy (Bowling et al., 2005).

With these data we can evaluate our hypothesis, that seasonal differences in the relationship between the mole fraction and stable isotope content of $\mathrm{CO}_{2}$ in forest air will be apparent due to local forest carbon exchange processes that overlay a larger scale (i.e. regional) variation in atmospheric $\mathrm{CO}_{2}$. We compared $\left[\mathrm{CO}_{2}\right]$ and $\delta^{13} \mathrm{C}$ of $\mathrm{CO}_{2}$ at four time periods over 2006 and 2007 (Fig. 6). During winter at the Niwot Ridge forest, trees are largely dormant, soil and air temperatures are at or below freezing, and respiration dominates the net carbon flux (Monson et al., 2006). During this time, ecosystem respiration drove $\left[\mathrm{CO}_{2}\right]$ of forest air higher and $\delta^{13} \mathrm{C}$ lower relative to values of the regional atmosphere (represented by flasks collected at the NWR alpine tundra site, Fig. 6a and c). NWR flask samples during these winter periods showed annual maxima in $\left[\mathrm{CO}_{2}\right]$ and minima in $\delta^{13} \mathrm{C}$ (Fig. 5). In these cases it appears that local forest processes (respiration) as well as larger-scale effects of ecosystem respiration increased the $\left[\mathrm{CO}_{2}\right]$ and decreased the $\delta^{13} \mathrm{C}$ of $\mathrm{CO}_{2}$ in the background air at this site (Trolier et al., 1996; Lai et al., 2004). During late summer and fall (August and September), regional $\left[\mathrm{CO}_{2}\right]$ reached an annual minimum and $\delta^{13} \mathrm{C}$ an annual maximum (Fig. 5). Within the forest in summer, photosynthesis and respiration affected the $\left[\mathrm{CO}_{2}\right]$ and $\delta^{13} \mathrm{C}$ of forest air (Fig. 6b and d). During the day, photosynthetic 
uptake reduced $\left[\mathrm{CO}_{2}\right]$ at $11 \mathrm{~m}$ by $5-10 \mu \mathrm{mol} \mathrm{mol}^{-1}$ below that observed in winter (dotted lines), with a commensurate increase in $\delta^{13} \mathrm{C}$. At night, respiratory fluxes of $\mathrm{CO}_{2}$ were greater lower in the canopy, presumably due to the influence of canopy- and soil-respired $\mathrm{CO}_{2}$. This led to higher $\left[\mathrm{CO}_{2}\right]$ and more negative $\delta^{13} \mathrm{C}$ at $11 \mathrm{~m}$ height at night relative to the regional atmosphere (Fig. 6b and d). NWR flask samples (all collected during the day) showed $\left[\mathrm{CO}_{2}\right]$ and $\delta^{13} \mathrm{C}$ values that compared most closely to daytime TDLAS data. Differences between NWR and the local forest during summer daytime periods were due to local net forest carbon uptake. The global or hemisphere-scale increase in $\left[\mathrm{CO}_{2}\right]$ is also apparent at both regional (NWR) and forest scales (Figs. 5 and 6). The mean $\left[\mathrm{CO}_{2}\right]$ of flask samples from the winter (Fig. $6 \mathrm{a}$ and c) increased approximately $2 \mu \mathrm{mol} \mathrm{mol}^{-1}$ from 2006 to 2007, as did the lower $\left[\mathrm{CO}_{2}\right]$ bound of the TDLAS data (Figs. 5 and 6).

\section{Summary}

In this study we have examined the performance of a fieldbased, commercially-available tunable diode laser absorption spectrometer for measuring the mole fraction and stable isotopic composition of $\mathrm{CO}_{2}$ in air for studies of biosphereatmosphere gas exchange. Over 500,000 measurements were made at several heights in and above a subalpine forest canopy in Colorado, USA. The data record at the Niwot Ridge forest presented here spans 2.4 years (and sampling continues). We obtained precisions of $0.2 \mu \mathrm{mol} \mathrm{mol}^{-1}$ for $\left[\mathrm{CO}_{2}\right]$ and 0.2 to $0.35 \%$ for $\delta^{13} \mathrm{C}$ of $\mathrm{CO}_{2}$, with the possibility of a bias in $\delta^{13} \mathrm{C}$ of $0.2 \%$. Comparison of actual and measured $\mathrm{CO}_{2}$ and $\delta^{13} \mathrm{C}$ of quality control tanks suggests that there may be a small positive bias in our $\delta^{13} \mathrm{C}$ measurements, or it may be due to a field-use related tank offset. This suggests that over long time periods (i.e. years) the $\delta^{13} \mathrm{C}$ of calibration tanks may change and periodic re-measurement is recommended. Comparison of TDLAS measurements with those from independent flask samples showed a small but persistent difference $\left(<0.5 \mu \mathrm{mol} \mathrm{mol}^{-1}\right)$ for $\left[\mathrm{CO}_{2}\right]$ and no difference for $\delta^{13} \mathrm{C}$ of $\mathrm{CO}_{2}$. The TDLAS data were used to interpret seasonal patterns in $\left[\mathrm{CO}_{2}\right]$ and $\delta^{13} \mathrm{C}$ within and above the forest canopy and to compare to regional variation. Time periods when trees were dormant (winter) showed the clear influences of local forest respiration on $\left[\mathrm{CO}_{2}\right]$ and $\delta^{13} \mathrm{C}$ on the air within the forest, and this influence was apparent at the regional scale as well. During the growing season (spring and summer) there were clear differences in the relative influence of photosynthesis and respiration on the $\left[\mathrm{CO}_{2}\right]$ and $\delta^{13} \mathrm{C}$ of forest air at different heights within the canopy. The high sampling frequency of the TDLAS showed clearly how these local-scale processes are overlaid upon regional/global patterns in $\left[\mathrm{CO}_{2}\right]$ and $\delta^{13} \mathrm{C}$ due to biological processes and anthropogenic $\mathrm{CO}_{2}$ release.
Acknowledgements. S. Sargent of Campbell Scientific, Inc. was extremely helpful with this analysis, and deserves considerable thanks for his ongoing dedication to high-quality instrumentation. Thanks to K. Chowanski, M. Losleben, L. Zukiewicz, K. Matheson, D. Millar, S. Burns, J. Knowles, and K. Ranno for excellent field support, R. Monson and S. Burns for sharing data from the Niwot Ridge AmeriFlux tower, S. Englund at the INSTAAR Stable Isotope Lab for analyses, and T. Conway at NOAA CCGG for sharing flask data. Help with calibration gas preparation at Utah was supplied by A. Schauer, S. Gaines, S. Bill, and M. Moody. This research was supported by a grant to DRB and JBM from the Office of Science (BER), U.S. Department of Energy, Grant No. DE-FG02-04ER63904 as part of the North American Carbon Program, and ongoing funding by the NOAA Carbon Cycle Greenhouse Gases Group, U.S. Department of Commerce, NOAA ESRL, Global Monitoring Division.

Edited by: A. B. Guenther

\section{References}

Allison, C. E. and Francey, R. J.: Verifying Southern Hemisphere trends in atmospheric carbon dioxide stable isotopes, J. Geophys. Res., 112, D21304, doi:10.1029/2006JD007345, 2007.

Alstad, K. P., Lai, C.-T., Flanagan, L. B., and Ehleringer, J. R.: Environmental controls on the carbon isotope composition of ecosystem-respired $\mathrm{CO}_{2}$ in contrasting forest ecosystems in Canada and the USA, Tree Physiol., 27, 1361-1374, 2007.

Bakwin, P. S., Tans, P. P., White, J. W. C., and Andres, R. J.: Determination of the isotopic $\left({ }^{13} \mathrm{C} /{ }^{12} \mathrm{C}\right)$ discrimination by terrestrial biology from a global network of observations, Global Biogeochem. Cy., 12, 555-562, 1998.

Barbour, M. M., Farquhar, G. D., Hanson, D. T., Bickford, C. P., Powers, H., and McDowell, N. G.: A new measurement technique reveals temporal variation in $\delta^{18} \mathrm{O}$ of leaf-respired $\mathrm{CO}_{2}$, Plant Cell Environ., 30, 456-468, 2007a.

Barbour, M. M., McDowell, N. G., Tcherkez, G., Bickford, C. P., and Hanson, D. T.: A new measurement technique reveals rapid post-illumination changes in the carbon isotope composition of leaf-respired $\mathrm{CO}_{2}$, Plant Cell Environ., 30, 469-482, $2007 \mathrm{~b}$.

Becker, J. F., Sauke, T. B., and Loewenstein, M.: Stable isotope analysis using tunable diode laser spectroscopy, Appl. Optics, 31, 1921-1927, 1992.

Bowling, D. R., Sargent, S. D., Tanner, B. D., and Ehleringer, J. R.: Tunable diode laser absorption spectroscopy for stable isotope studies of ecosystem-atmosphere $\mathrm{CO}_{2}$ exchange, Agr. Forest Meteorol., 118, 1-19, 2003.

Bowling, D. R., Burns, S. P., Conway, T. J., Monson, R. K., and White, J. W. C.: Extensive observations of $\mathrm{CO}_{2}$ carbon isotope content in and above a high-elevation subalpine forest, Global Biogeochem. Cy., 19, GB3023, doi:10.1029/2004GB002394, 2005.

Bowling, D. R., Pataki, D. E., and Randerson, J. T.: Carbon isotopes in terrestrial ecosystem pools and $\mathrm{CO}_{2}$ fluxes, New Phytol., 178, 24-40, 2008.

Brand, W. A.: High Precision Isotope Ratio Monitoring Techniques in Mass Spectrometry, J. Mass Spectrom., 31, 225-235, 1996. 
Ciais, P., Tans, P. P., White, J. W. C., Trolier, M., Francey, R. J., Berry, J. A., Randall, D. R., Sellers, P. J., Collatz, J. G., and Schimel, D. S.: Partitioning of ocean and land uptake of $\mathrm{CO}_{2}$ as inferred by $\delta^{13} \mathrm{C}$ measurements from the NOAA Climate Monitoring and Diagnostics Laboratory Global Air Sampling Network, J. Geophys. Res., 100, 5051-5070, 1995.

Craig, H.: Isotopic standards for carbon and oxygen and correction factors for mass-spectrometric analysis of carbon dioxide, Geochim. Cosmochim. Ac., 12, 133-149, 1957.

Crosson, E. R., Ricci, K. N., Richman, B. A., Chilese, F. C., Owano, T. G., Provencal, R. A., Todd, M. W., Glasser, J., Kachanov, A. A., Paldus, B. A., Spence, T. G., and Zare, R. N.: Stable isotope ratios using cavity ring-down spectroscopy: Determination of ${ }^{13} \mathrm{C} /{ }^{12} \mathrm{C}$ for carbon dioxide in human breath, Anal. Chem., 74, 2003-2007, 2002.

Esler, M. B., Griffith, D. W. T., Wilson, S. R., and Steele, L. P.: Precision trace gas analysis by FT-IR spectroscopy. 2. The ${ }^{13} \mathrm{C} /{ }^{12} \mathrm{C}$ isotope ratio of $\mathrm{CO}_{2}$, Anal. Chem., 72, 216-221, 2000.

Farquhar, G. D., Ehleringer, J. R., and Hubick, K. T.: Carbon isotope discrimination and photosynthesis, Annu. Rev. Plant Phys., 40, 503-537, 1989.

Fisher, R., Lowry, D., Wilkin, O., Sriskantharajah, S., and Nisbet, E. G.: High-precision, automated stable isotope analysis of atmospheric methane and carbon dioxide using continuous-flow isotope-ratio mass spectrometry, Rapid Commun. Mass Sp., 20, 200-208, 2006.

Francey, R. J., Tans, P. P., Allison, C. E., Enting, I. G., White, J. W. C., and Trolier, M.: Changes in oceanic and terrestrial carbon uptake since 1982, Nature, 373, 326-330, 1995.

Francey, R. J., Allison, C. E., Etheridge, D. M., Trudinger, C. M., Enting, I. G., Leuenberger, M., Langenfelds, R. L., Michel, E., and Steele, L. P.: A 1000-year high precision record of $\delta^{13} \mathrm{C}$ in atmospheric $\mathrm{CO}_{2}$, Tellus, 51B, 170-193, 1999.

Griffis, T. J., Baker, J. M., Sargent, S. D., Tanner, B. D., and Zhang, J.: Measuring field-scale isotopic $\mathrm{CO}_{2}$ fluxes with tunable diode laser absorption spectroscopy and micrometeorological techniques, Agr. Forest Meteorol., 124, 15-29, 2004.

Griffis, T. J., Baker, J. M., and Zhang, J.: Seasonal dynamics and partitioning of isotopic $\mathrm{CO}_{2}$ exchange in a $\mathrm{C}_{3} / \mathrm{C}_{4}$ managed ecosystem, Agr. Forest Meteorol., 132, 1-19, 2005 a.

Griffis, T. J., Lee, X., Baker, J. M., Sargent, S. D., and King, J. Y.: Feasibility of quantifying ecosystem-atmosphere $\mathrm{C}^{18} \mathrm{O}^{16} \mathrm{O}$ exchange using laser spectroscopy and the flux-gradient method, Agr. Forest Meteorol., 135, 44-60, 2005b.

Griffis, T. J., Zhang, J., Baker, J. M., Kljun, N., and Billmark, K.: Determining carbon isotope signatures from micrometeorological measurements: Implications for studying biosphereatmosphere exchange processes, Bound.-Lay. Meteorol., 123, 295-316, 2007.

Griffith, D. W. T., Toon, G. C., Sen, B., Blavier, J. F., and Toth, R. A.: Vertical profiles of nitrous oxide isotopomer fractionation measured in the stratosphere, Geophys. Res. Lett., 27, 24852488, 2000.

Gulluk, T., Wagner, H. E., and Slemr, F.: A high-frequency modulated tunable diode laser absorption spectrometer for measurements of $\mathrm{CO}_{2}, \mathrm{CH}_{4}, \mathrm{~N}_{2} \mathrm{O}$, and $\mathrm{CO}$ in air samples of a few $\mathrm{cm}^{3}$, Rev. Sci. Instrum., 68, 230-239, 1997.

Hoefs, J.: Stable Isotope Geochemistry, Springer, Berlin, 201 pp., 1997.
Keeling, C. D., Whorf, T. P., Wahlen, M., and van der Plicht, J.: Interannual extremes in the rate of rise of atmospheric carbon dioxide since 1980, Nature, 375, 666-670, 1995.

Knohl, A.: Carbon dioxide exchange and isotopic signature $\left({ }^{13} \mathrm{C}\right)$ of an unmanaged 250 year-old deciduous forest, $\mathrm{PhD}$ dissertation, FS Universitat Jena, Germany, 2003.

Knohl, A. and Buchmann, N.: Partitioning the net $\mathrm{CO}_{2}$ flux of a deciduous forest into respiration and assimilation using stable carbon isotopes, Global Biogeochem. Cy., 19, GB4008, doi:10.1029/2004GB002301, 2005.

Knohl, A., Werner, R. A., Brand, W. A., and Buchmann, N.: Shortterm variations in $\delta^{13} \mathrm{C}$ of ecosystem respiration reveals link between assimilation and respiration in a deciduous forest, Oecologia, 142, 70-82, 2005.

Lai, C.-T., Ehleringer, J. R., Schauer, A. J., Tans, P. P., Hollinger, D. Y., Paw U, K. T., Munger, J. W., and Wofsy, S. C.: Canopy-scale $\delta^{13} \mathrm{C}$ of photosynthetic and respiratory $\mathrm{CO}_{2}$ fluxes: observations in forest biomes across the United States, Glob. Change Biol., 11, 633-643, 2005.

Lai, C. T., Ehleringer, J. R., Tans, P., Wofsy, S. C., Urbanski, S. P., and Hollinger, D. Y.: Estimating photosynthetic ${ }^{13} \mathrm{C}$ discrimination in terrestrial $\mathrm{CO}_{2}$ exchange from canopy to regional scales, Global Biogeochem. Cy., 18, GB1041, doi:10.1029/2003GB002148, 2004.

Lai, C. T., Riley, W., Owensby, C., Ham, J., Schauer, A., and Ehleringer, J. R.: Seasonal and interannual variations of carbon and oxygen isotopes of respired $\mathrm{CO}_{2}$ in a tallgrass prairie: Measurements and modeling results from 3 years with contrasting water availability, J. Geophys. Res.-Atmos., 111, D08S06, doi:10.1029/2005JD006436, 2006.

Lee, X., Sargent, S., Smith, R., and Tanner, B.: In situ measurement of the water vapor ${ }^{18} \mathrm{O} /{ }^{16} \mathrm{O}$ isotope ratio for atmospheric and ecological applications, J. Atmos. Ocean. Tech., 22, 555-565, 2005.

Masarie, K. A., Langenfelds, R. L., Allison, C. E., Conway, T. J., Dlugokencky, E. J., Francey, R. J., Novelli, P. C., Steele, L. P., Tans, P. P., Vaughn, B., and White, J. W. C.: NOAA/CSIRO Flask Air Intercomparison Experiment: A strategy for directly assessing consistency among atmospheric measurements made by independent laboratories, J. Geophys. Res.-Atmos., 106, $20445-$ $20464,2001$.

McManus, J. B., Nelson, D. D., Shorter, J. H., Jimenez, R., Herndon, S., Saleska, S., and Zahniser, M.: A high precision pulsed quantum cascade laser spectrometer for measurements of stable isotopes of carbon dioxide, J. Mod. Optic., 52, 2309-2321, 2005.

Monson, R. K., Turnipseed, A. A., Sparks, J. P., Harley, P. C., ScottDenton, L. E., Sparks, K., and Huxman, T. E.: Carbon sequestration in a high-elevation, subalpine forest, Glob. Change Biol., 8, 459-478, 2002.

Monson, R. K., Burns, S. P., Williams, M. W., Delany, A. C., Weintraub, M., and Lipson, D. A.: The contribution of beneath-snow soil respiration to total ecosystem respiration in a high-elevation, subalpine forest, Global Biogeochem. Cy., 20, GB3030, doi:10.1029/2005GB002684, 2006.

Mortazavi, B., Chanton, J. P., Prater, J. L., Oishi, A. C., Oren, R., and Katul, G.: Temporal variability in ${ }^{13} \mathrm{C}$ of respired $\mathrm{CO}_{2}$ in a pine and a hardwood forest subject to similar climatic conditions, Oecologia, 142, 57-69, 2005. 
Mortazavi, B., Chanton, J. P., and Smith, M. C.: Influence of ${ }^{13} \mathrm{C}$-enriched foliage respired $\mathrm{CO}_{2}$ on $\delta^{13} \mathrm{C}$ of ecosystem-respired $\mathrm{CO}_{2}$, Global Biogeochem. Cy., 20, GB3029, doi:10.1029/2005GB002650, 2006.

Murnick, D. E. and Peer, B. J.: Laser-based analysis of carbon isotope ratios, Science, 263, 945-947, 1994.

Murnick, D. E. and Okil, J. O.: Use of the optogalvanic effect (OGE) for isotope ratio spectrometry of ${ }^{13} \mathrm{CO}_{2}$ and ${ }^{14} \mathrm{CO}_{2}$, Isot. Environ. Healt. S., 41, 363-371, 2005.

Ogee, J., Peylin, P., Ciais, P., Bariac, T., Brunet, Y., Berbigier, P., Roche, C., Richard, P., Bardoux, G., and Bonnefond, J.M.: Partitioning net ecosystem carbon exchange into net assimilation and respiration using ${ }^{13} \mathrm{CO}_{2}$ measurements: A costeffective sampling strategy, Global Biogeochem. Cy., 17, 1070, doi:10.1029/2002GB001995, 2003.

Pataki, D. E., Ehleringer, J. R., Flanagan, L. B., Yakir, D., Bowling, D. R., Still, C. J., Buchmann, N., Kaplan, J. O., and Berry, J. A.: The application and interpretation of Keeling plots in terrestrial carbon cycle research, Global Biogeochem. Cy., 17, 1022, doi:10.1029/2001GB001850, 2003.

Pataki, D. E., Bowling, D. R., Ehleringer, J. R., and Zobitz, J. M.: High resolution atmospheric monitoring of urban carbon dioxide sources, Geophys. Res. Lett., 33, L03813, doi:10.1029/2005GL024822, 2006.

Provencal, R., Gupta, M., Owano, T. G., Baer, D. S., Ricci, K. N., O'Keefe, A., and Podolske, J. R.: Cavity-enhanced quantumcascade laser-based instrument for carbon monoxide measurements, Appl. Optics, 44, 6712-6717, 2005.

Sacks, W. J., Schimel, D. S., and Monson, R. K.: Coupling between carbon cycling and climate in a high-elevation, subalpine forest: a model-data fusion analysis, Oecologia, 151, 54-68, 2007.

Saleska, S. R., Shorter, J. H., Herndon, S., Jimenez, R., McManus, B., Munger, J. W., Nelson, D. D., and Zahniser, M. S.: What are the instrumentation requirements for measuring the isotopic composition of net ecosystem exchange of $\mathrm{CO} 2$ using eddy covariance methods?, Isot. Environ. Healt. S., 42, 115-133, 2006.

Schaeffer, S. M., Anderson, D. E., Burns, S. P., Monson, R. K., Sun, J., and Bowling, D. R.: Canopy structure and atmospheric flows in relation to the $\delta^{13} \mathrm{C}$ of respired $\mathrm{CO}_{2}$ in a subalpine coniferous forest, Agr. Forest Meteorol., 148, 592-605, 2008.

Schauer, A. J., Lott, M. J., Cook, C. S., and Ehleringer, J. R.: An automated system for stable isotope and concentration analyses of $\mathrm{CO}_{2}$ from small atmospheric samples, Rapid Commun. Mass Sp., 19, 359-362, 2005.
Scholze, M., Kaplan, J. O., Knorr, W., and Heimann, M.: Climate and interannual variability of the atmospherebiosphere ${ }^{13} \mathrm{CO}_{2}$ flux, Geophys. Res. Lett., 30, 1097, doi:10.1029/2002GL015631, 2003.

Tans, P. P., Bakwin, P. S., and Guenther, D. W.: A feasible global carbon cycle observing system: a plan to decipher today's carbon cycle based on observations, Glob. Change Biol., 2, 309-318, 2005.

Trolier, M., White, J. W. C., Tans, P. P., Masarie, K. A., and Gemery, P. A.: Monitoring the isotopic composition of atmospheric $\mathrm{CO}_{2}$ : Measurements from the NOAA Global Air Sampling Network, J. Geophys. Res.-Atmos., 101, 25 897-25 916, 1996.

Turnipseed, A. A., Blanken, P. D., Anderson, D. E., and Monson, R. K.: Energy budget above a high-elevation subalpine forest in complex topography, Agr. Forest Meteorol., 110, 177-201, 2002.

Vaughn, B. H., Ferretti, D. F., Miller, J., and White, J. W. C.: Stable isotope measurements of atmospheric $\mathrm{CO}_{2}$ and $\mathrm{CH}_{4}$, in: Handbook of Stable Isotope Analytical Techniques, edited by: de Groot, P. A., Elsiever, Amsterdam, 272-304, 2004.

Wahl, E. H., Fidric, B., Rella, C. W., Koulikov, S., Kharlamov, B., Tan, S., Kachanov, A. A., Richman, B. A., Crosson, E. R., Paldus, B. A., Kalaskar, S., and Bowling, D. R.: Applications of cavity ring-down spectroscopy to high precision isotope ratio measurement of ${ }^{13} \mathrm{C} /{ }^{12} \mathrm{C}$ in carbon dioxide, Isot. Environ. Healt. S., 42, 21-35, 2006.

Webster, C. R., Flesch, G. J., Scott, D. C., Swanson, J. E., May, R. D., Woodward, W. S., Gmachl, C., Capasso, F., Sivco, D. L., Baillargeon, J. N., Hutchinson, A. L., and Cho, A. Y.: Quantumcascade laser measurements of stratospheric methane and nitrous oxide, Appl. Optics, 40, 321-326, 2001.

Weidmann, D., Wysocki, G., Oppenheimer, C., and Tittel, F. K.: Development of a compact quantum cascade laser spectrometer for field measurements of $\mathrm{CO}_{2}$ isotopes, Appl. Phys. B-Lasers O., 80, 255-260, 2005.

Zhang, J., Griffis, T. J., and Baker, J. M.: Using continuous stable isotope measurements to partition net ecosystem $\mathrm{CO}_{2}$ exchange, Plant Cell Environ., 29, 483-496, 2006.

Zhang, Q. L. and Li, W.-J.: A calibrated measurement of the atomic weight of carbon, Chinese Sci. Bull., 35, 290-296, 1990. 